\title{
Review \\ Different Approaches in Therapy Aiming to Stabilize an Unstable Atherosclerotic Plaque
}

\author{
Michal Kowara and Agnieszka Cudnoch-Jedrzejewska *
}

check for updates

Citation: Kowara, M.; CudnochJedrzejewska, A. Different Approaches in Therapy Aiming to Stabilize an Unstable Atherosclerotic Plaque. Int. J. Mol. Sci. 2021, 22, 4354. https://doi.org/10.3390/ ijms22094354

Academic Editor: Eva Kassi

Received: 28 February 2021

Accepted: 14 April 2021

Published: 21 April 2021

Publisher's Note: MDPI stays neutral with regard to jurisdictional claims in published maps and institutional affiliations.

Copyright: (c) 2021 by the authors. Licensee MDPI, Basel, Switzerland. This article is an open access article distributed under the terms and conditions of the Creative Commons Attribution (CC BY) license (https:// creativecommons.org/licenses/by/ $4.0 /)$.
Laboratory of Centre for Preclinical Research, Department of Experimental and Clinical Physiology, Medical University of Warsaw, 02-091 Warsaw, Poland; michal.kowara@wum.edu.pl

* Correspondence: agnieszka.cudnoch@wum.edu.pl

\begin{abstract}
Atherosclerotic plaque vulnerability is a vital clinical problem as vulnerable plaques tend to rupture, which results in atherosclerosis complications-myocardial infarctions and subsequent cardiovascular deaths. Therefore, methods aiming to stabilize such plaques are in great demand. In this brief review, the idea of atherosclerotic plaque stabilization and five main approaches-towards the regulation of metabolism, macrophages and cellular death, inflammation, reactive oxygen species, and extracellular matrix remodeling have been presented. Moreover, apart from classical approaches (targeted at the general mechanisms of plaque destabilization), there are also alternative approaches targeted either at certain plaques which have just become vulnerable or targeted the minimization of the consequences of atherosclerotic plaque erosion or rupture. These alternative approaches have also been briefly mentioned in this review.
\end{abstract}

Keywords: atherosclerotic plaque; stabilization; vulnerable plaque; inflammation; macrophage; intravascular ultrasound; myocardial infarction; necrotic cores; cell death

\section{Introduction}

Atherosclerotic plaque is the pathophysiological basis of ischemic heart disease-a widespread disease in both developed and developing countries [1]. A principal complication of ischemic heart disease is myocardial infarction, which constitutes the main cause of mortality worldwide [2]. Myocardial infarction is a consequence of the sudden occlusion of the coronary artery supplying the myocardial tissue, which is caused mainly $(75 \%$ of the time) by atherosclerotic plaque rupture and thrombus generation [3-5]. This deficiency in the oxygen supply leads to myocardial cell damage and necrosis which compromises the entire heart activity and might result in ion current disturbances leading to life-threatening ventricular arrhythmias [6,7]. The development of atherosclerotic plaque is a long process composed of several stages (Figure 1).

Briefly, apo-B containing lipoproteins (especially LDL) pass through the endothelial layer of the arterial intima and accumulate within the subendothelial area where they are endocytosed by intimal macrophages. Simultaneously, local blood flow disturbances (nonlinear flow) in atherosclerosis-susceptible regions (e.g., arterial branches) cause decreased shear stress that is detected by the endothelial cells in the process of mechanotransduction. These processes change the microenvironment of the arterial wall intima, which promotes subsequent alterations-foam cell generation, vascular smooth muscle cell migration, and their conversion from contractile into the synthetic phenotype, extracellular matrix remodeling, plaque growth, fibrous cap formation, and finally, necrotic core formation and calcifications [8,9]. In addition, Peter Libby emphasized the crucial role of the immune system in atherogenesis [10]. Many plaques develop into stable structures which manifest clinically as chronic coronary syndrome, but some of them undergo special ultrastructural alterations making them prone to rupture. Such plaques are called 'unstable' or 'vulnerable' [11]. According to the classic definition created by Virmani, vulnerable plaque is a thin-cap fibroatheroma (TCFA), characterized by a necrotic core presence with an 
overlying fibrous cap of thickness $<65 \mu \mathrm{m}$ [12]. The processes leading to plaque destabilization, i.e., apoptosis of VSMC within the fibrous cap, neovascularization, and necrotic core enlargement, are presented in Figure 2 [13].

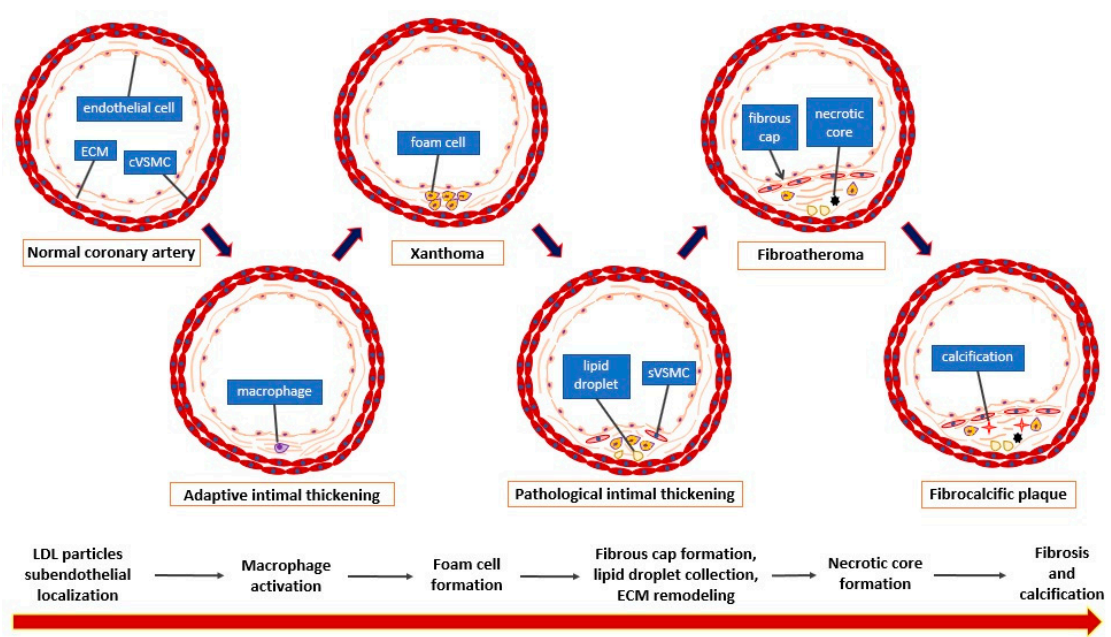

Figure 1. Stages of atherosclerotic plaque development (according to the Virmani classification [6]). cVSMC: vascular smooth muscle cell, contractile phenotype; sVSMC: vascular smooth muscle cell, synthetic phenotype; ECM: extracellular matrix.

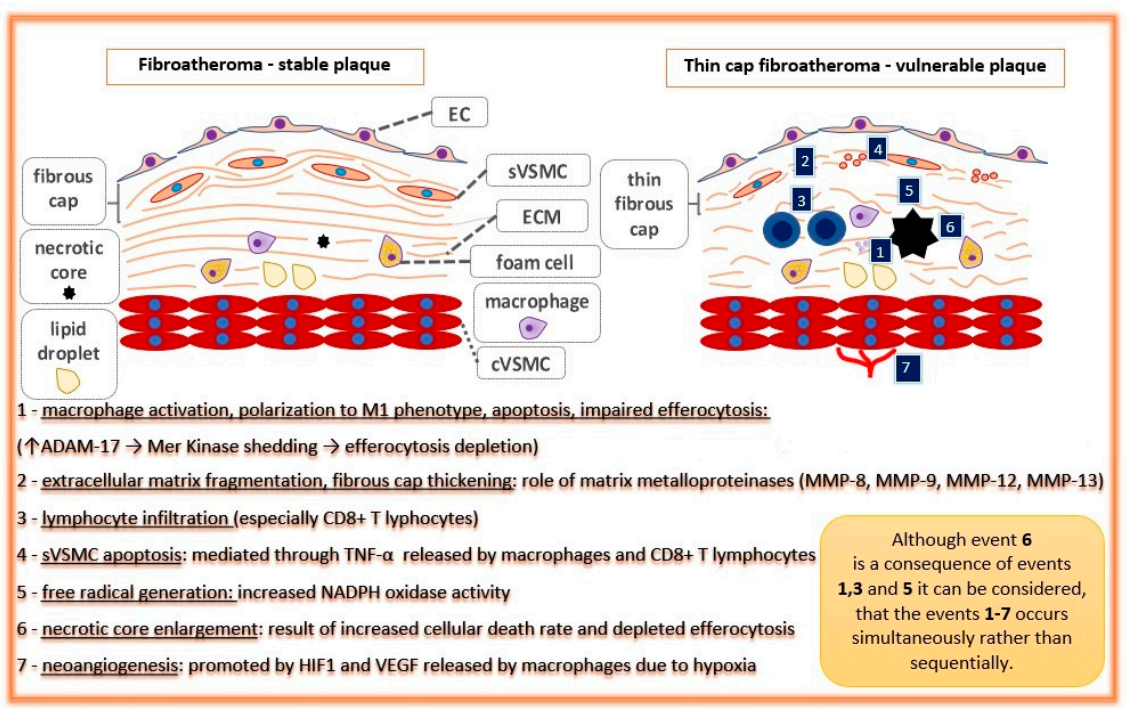

Figure 2. Pathophysiological processes and events leading to atherosclerotic plaque destabilization (events 1-7 in blue boxes). EC: endothelial cell; cVSMC: vascular smooth muscle cell, contractile phenotype; sVSMC: vascular smooth muscle cell, synthetic phenotype; ECM: extracellular matrix.

The occurrence of major cardiovascular adverse events (MACE—composite endpoint composed of death from cardiac causes, cardiac arrest, myocardial infarction, or rehospitalization because of unstable or progressive angina) relies on the presence of vulnerable plaques. A PROSPECT study on 697 patients with acute coronary syndrome treated with PCI revealed that the cumulative rate of MACE during a three-year follow-up referred to untreated, non-culprit lesions was significantly and independently correlated with the presence of thin-cap fibroatheroma on intravascular ultrasonography [14]. Therefore, therapies aimed at promoting atherosclerotic plaque stabilization would be warranted. However, because thin-cap fibroatheromas and stable fibroatheromas can transform into one another and the occurrence of vulnerable atherosclerotic plaque might be underestimated in clinical studies due to clinical silence, the optimal therapy aimed at stabilizing plaques should 
be concentrated on the promotion of molecular stabilizing pathways 'in general' rather than on the stabilization of certain atherosclerotic lesions (considered vulnerable on imaging) [15]. In this review, we summarize the crucial approaches towards plaque stabilization, and we present the clinical studies based on them.

\section{General Considerations}

Antiatherosclerotic properties are important features of certain drugs or chemical compounds. Indeed, a plethora of different substances-from precisely targeted molecules to traditional Chinese medicinal herbs, nutrients, or even gases such as hydrogen have been extensively investigated in search of their potentially beneficial impact on atherosclerotic plaques [16-19]. The animal models widely used in such investigations are genetically modified (ApoE-/ - or LDL- / -) mice as well as WHHL (Watanabe-heritable hyperlipidemic) rabbits $[20,21]$. In such investigations, a vulnerable atherosclerotic plaque is obtained through dietary modification (i.e., high-fat diets containing high cholesterol) together with interventions such as angiotensin II infusion via an osmotic pump, cast placement around the common carotid artery, or balloon injury (in rabbits) [22,23]. Then, the animals are divided into a control group (receiving a saline solution) and the experimental group (receiving the study compound). When the study is finished, the vulnerable plaque indicators are assessed by immunohistochemical analysis in both animal groups. Although many preclinically investigated compounds have presented antiatherosclerotic features, only a minority of them have been proven to be clinically relevant. This situation occurs not only due to dissimilarities between the pathophysiology of atherosclerotic plaque development in animals and humans but also because of the difficulties in the design and performance of applicable clinical studies. Nevertheless, experiments with animal models make it possible to investigate different approaches towards plaque stabilization.

\section{Approaches Directed at Specific Molecular Pathways}

\subsection{Approach towards Regulation of Metabolism}

Knowledge about vulnerable atherosclerotic plaque development makes it possible to investigate whether therapies targeted at specific molecular pathways are able to stabilize it. One kind of such therapy is directed towards the modulation of metabolism. Oxidized low-density lipoproteins are considered to be crucial elements in the process of plaque initiation and progression; therefore, interventions aiming to decrease their level are considered plaque-stabilizing. Lipid-lowering agents, such as statins (hydroxymethylglutaryl-CoA synthase, i.e., cholesterol-synthesizing enzyme inhibitors), ezetimibe (an inhibitor of intestinal cholesterol absorption and Niemann-Pick C1-Like 1 antagonist), and alirocumab (antibody blocking proprotein convertase subtilisin/kexin type 9 and increasing LDL-LDLR recycling) improved atherosclerotic plaque stability in different animal models [21,24-26]. Contrary to the LDL particles, high-density lipoproteins (HDL) are considered atheroprotective because of reverse cholesterol transport promotion from lesional macrophages to the liver via interaction with the ATP-binding cassette transporter ABCA1 [27]. It has been demonstrated that recombinant HDL particles (especially Milano type rather than wild-type) promote plaque stability by decreasing intraplaque MMP-2 activity and the chemokine MCP-1 level when compared with a placebo in atherosclerotic New Zealand White rabbits [28]. The cholesteryl ester transfer protein (CETP) inhibitor anacetrapib, which increases HDL levels in serum, also presented similar antiatherosclerotic properties in mice [29]. However, even preclinical studies have demonstrated that LDL level reduction is more important in atherosclerotic plaque stabilization than an increase in HDL [30]. Apart from the lipids, glucose at higher concentrations also participates in the destabilization of atherosclerotic plaque. A study on diabetic ApoE-/- mice showed that hyperglycemia destabilizes the plaque via the inhibition of AMPK $\alpha$ and its target gene, prolyl-4-hydroxylase alpha $1(\mathrm{P} 4 \mathrm{H} \alpha 1)$, an enzyme participating in collagen synthesis [31]. In consequence, hypoglycemic medications are supposed to be plaque-stabilizing and are therefore antiatherosclerotic agents. 


\subsection{Approach towards Macrophages and Cellular Death Mechanisms}

Macrophages contribute significantly to the process of atherosclerotic plaque destabilization. On the one hand, they orchestrate different, sometimes opposite, reactions and molecular pathways within the plaque microenvironment, promoting either plaque instability (M1 subpopulation) or plaque stability (M2 subpopulation) [32]. On the other hand, their conversion into lipid-laden foam cells and subsequent cellular death (in particular through necrosis or necroptosis, i.e., programmed necrosis) lead directly to necrotic core enlargement and plaque destabilization [33]. The situation is different when macrophages undergo typical programmed cellular death, i.e., apoptosis, which can be even atheroprotective in the initial phase of plaque development [34]. However, for plaque stability, it is necessary that the apoptotic bodies are robustly cleared through efferocytosis [35]. Another mechanism of cellular death that prevents plaque destabilization is autophagy, in which damaged organelles or cellular compartments are sequestrated into double-membrane structures called autophagosomes and then degraded by lysosomes [36]. Therefore, molecular pathways preventing macrophage conversion into foam cells or necrosis, as well as pathways promoting autophagy and appropriate clearance of apoptotic bodies (efferocytosis), may be atheroprotective. A study has demonstrated that ApoE-/- mice receiving arglabine, an NLRP3 antagonist which redirects macrophages towards autophagic pathways, presented a decreased level of IL-1 $\beta$ (a marker of inflammation) in plasma and reduced atherosclerotic lesions when compared with ApoE-/- mice from the control group [37]. For appropriate efferocytosis, a Mer Tyrosine Kinase (MerTK) expressed on the macrophage surface is required and pathways, which promote MerTK shedding from a membrane to the soluble form, impair this process. For instance, angiotensin II negatively affects efferocytosis through ADAM17 activation and subsequent MerTK shedding [38]. Apart from the aspects of cellular death, interventions preventing macrophage conversion into foam cells (such as inhibition of LOX-1, a receptor recognizing and internalizing oxLDL particles) as well as reverse cholesterol transport promotion in foam cells via $L X R \alpha$ receptor activation have been demonstrated to be atheroprotective in animal models [39-41].

\subsection{Approach toward Inflammation and Immune Reactions}

Vulnerable atherosclerotic plaques are characterized by a robust infiltration of different immune cells. Activation of lesional macrophages causes the production and secretion of diverse interleukins and chemokines, which subsequently drive immune cell infiltration $[42,43]$. Chemokines recruit neutrophils (CCL2) and T cells (CX3CL1, in more advanced lesions), whereas interleukins, such as IL-1 $\beta$, activate those cells. Moreover, the immune cells transport through the endothelial layer (diapedesis) depend on adhesive molecules, such as ICAM-1 and VCAM-1. Significant augmentation of T cells (especially $\mathrm{CD} 8+$, i.e., cytotoxic $\mathrm{T}$ cells) has been observed within atherosclerotic plaque in vulnerable plaque specimens (derived from a biobank of human aortas covering the full spectrum of atherosclerotic disease) [44]. Therefore, antagonizing immune reactions responsible for the inflammatory state within the plaque would be an interesting therapeutic option [45] As anticipated, inhibition of proinflammatory interleukins (such as IL-6) and chemokines (such as CXCL10) results in atherosclerotic plaque stabilization [46,47]. Interestingly, IL-1 $\beta$ inhibition over the entire time of plaque development in a mouse model resulted in a reduction in atherosclerotic plaque formation, but when such therapy was applied in mice with advanced lesions (from 18 to 24 weeks), not only was it not atheroprotective, but it also resulted in an increased number of macrophages within the plaque and abrogated beneficial remodeling $[48,49]$. This means that the entire system of interactions and reciprocal feedbacks during atherosclerotic plaque destabilization is very complex, and simple approaches (i.e., blocking factors that are considered to be proinflammatory) tend to be insufficient. For this reason, more general anti-inflammatory approaches are also used, for instance, colchicine, which has presented complex effects by inhibiting critical inflammatory signaling networks (inflammasome, proinflammatory cytokines, and adhesion molecules) $[50,51]$. Moreover, inflammatory mediators such as interleukins are under the 
control of transcription factors. For instance, an NF-кB transcriptional factor is considered to be a crucial element of the inflammatory response, and many plaque-stabilizing effects induced by different substances are accompanied by NF-кB suppression [52-54]. However, inflammatory pathways are also under the negative control of anti-inflammatory cytokines, and the promotion of anti-inflammatory pathways (e.g., genetic amplification of IL-37) presents a stabilizing effect on the plaque [55]. The cells responsible for the resolution of immune reactions are regulatory T cells (Tregs). It has been demonstrated in the ApoE- /mouse model that pioglitazone (an antidiabetic drug belonging to the thiazolidinedione group) stabilized the atherosclerotic plaque, which was accompanied by an increase in the number of Tregs within the lesion [56]. Moreover, there is the innovative idea of using vaccines against atherosclerosis. In contrast to vaccines against infectious agents, vaccines against atherosclerosis aim to induce immune tolerance towards core antigens involved in atherosclerotic plaque development (such as ApoB-100 on oxLDL particles). The principal way to gain tolerance is Treg induction through the injections of peptides-fragments of the target antigen. An additional way for such vaccination is the generation of neutralizing autoantibodies, for instance, against PCSK9, which demonstrate antiatherosclerotic properties. These effects can be obtained with the use of special techniques such as the use of adjuvants, neoepitope development technologies, and vaccine platforms (e.g., Q $\beta$ bacteriophage virus-like particles) [57].

\subsection{Approach towards Reactive Oxygen Species-Antioxidation Therapy}

Reactive oxygen species play a pivotal role in atherosclerotic plaque progression and subsequent destabilization. They are generated mainly by enzymes, such as NADPH oxidases (NOX) localized within endothelial cells, fibroblasts, and vascular smooth muscle cells, and their expression is upregulated by proinflammatory factors such as IL-1 $\beta$ or Ang II $[58,59]$. First, reactive oxygen species cause lipid oxidation, which generates oxidized cholesterol derivatives such as 7 -ketocholesterol $(7-\mathrm{K})$ and $7 \beta$ hydroxycholesterol $(7 \beta-\mathrm{OH})$. These compounds insert themselves into the cellular membrane and mediate a plethora of subsequent pathways inducing endothelial pump dysfunction, cell cycle blockade, and lysosomal or endoplasmic reticulum membrane damage in different cells (especially macrophages), leading to their apoptosis [60]. Second, reactive oxygen species cause direct damage to the DNA and promote mechanisms of cellular death in that way [61]. Moreover, oxidized cholesterol derivatives (27-hydroxycholesterol and aldehyde 4-hydroxynonenal) increase prostaglandin E production, which further enhances proinflammatory cytokines and matrix-degrading enzymes (especially matrix metalloproteinase 9), increasing the risk of atherosclerotic plaque rupture [62]. Reactive oxygen species are reciprocally linked with immune reactions. On the one hand, their production is under the control of proinflammatory cytokines such as TNF- $\alpha$. On the other hand, the products of ROS activity, such as oxidized cholesterol derivatives, promote the expression of proinflammatory cytokines, e.g., IL-1 $\beta$, TNF- $\alpha$, IL-8, or chemokine MCP- 1 , as has been demonstrated in ApoE- /mice lacking TNF- $\alpha$ and the human monocytic cell lines (U937 and THP-1) [63,64]. It is clear that the overproduction of reactive oxygen species is detrimental for the cells within the atherosclerotic plaque, and pathways induced by these agents may destabilize the plaque, leading to its rupture [65]. Therefore, pharmacological interventions leading to the neutralization of reactive oxygen species (either directly, in different mechanisms of antioxidation, or indirectly, by the abrogation of their generation) would be beneficial in atherosclerotic plaque stabilization. Interestingly, antioxidants are important food components, which leads to the idea that diet can be atheroprotective and plaque-stabilizing in that way. Indeed, many preclinical investigations on different nutrients have proven their stabilizing potential upon atherosclerotic plaque (such as soy isoflavones, vitamin E, carotenes, or xanthines) [66-69]. For example, ApoE - / - mice fed on blackberry extract rich with anthocyanin presented increased HDL levels and increased connective tissue content within the plaque, resulting in improved plaque stability when compared with the control group [70]. Moreover, the effect of stabilizing atherosclerotic plaques was also 
achieved by action on the controlling mechanisms; NOX2 (NADPH oxidase isoform 2, ROS generator) inhibition resulted in plaque stabilization, whereas Hsp70 (a protective chaperone) silencing resulted in plaque destabilization [71,72].

\subsection{Approach towards Extracellular Matrix Remodeling and Neovascularization}

It has to be emphasized that the entire plaque structure is based on scaffolding, i.e., an extracellular matrix (ECM) composed of collagens, elastin, proteoglycans, and fibronectin. These proteins constitute the connective tissue of the plaque. A fibrous cap, i.e., structure covering the plaque and maintaining its stability, is built up with vascular smooth muscle cells and macrophages embedded in collagen and elastin fibers. The appropriate, compact, and organized structure of the ECM component is crucial for plaque stability. Therefore, the influence on ECM protein synthesis or regulation by different methods (including miRNA) affects plaque stability [73-75]. The ECM structure is regulated by proteasescathepsins, serine proteases, and metalloproteinases-matrix metalloproteinases (MMPs), $\alpha$-disintegrin, metalloproteinases (ADAMs), and $\alpha$-disintegrin and metalloproteinases with thrombospondin domains (ADAMTSs). Although all the proteases perform ECM protein hydrolysis, this site-specific hydrolysis results in different changes within the scaffold-some alterations lead towards ECM fragmentation, and other alterations lead towards strengthening restructuring [76,77]. Therefore, some proteases stabilize the plaque (like ADAM15), and other proteases destabilize it (such as virtually all MMPs, especially MMP-9) [78,79]. A histological study on human carotid artery specimens has revealed that a more vulnerable plaque phenotype correlated with an increased MMP-14 level and a decreased TIMP-3 (an inhibitor of tissue metalloproteinase) level [80]. Finally, vulnerable plaques are also characterized by neovascularization and proangiogenic factors (such as bFGF or CD137), which are supposed to play a role in plaque destabilization [81-84]. An optical coherence tomography study on 53 patients has shown an increase in intraplaque neovessel volume in vulnerable and ruptured plaques [85]. In consequence, therapies targeting intraplaque angiogenesis (e.g., axitinib-an inhibitor of VEGF receptor-1, -2 , and $-3)$ are considered to be plaque-stabilizing $[86,87]$.

\subsection{Specific Approaches-Summary}

The abovementioned specific approaches are illustrated in Figure 3.

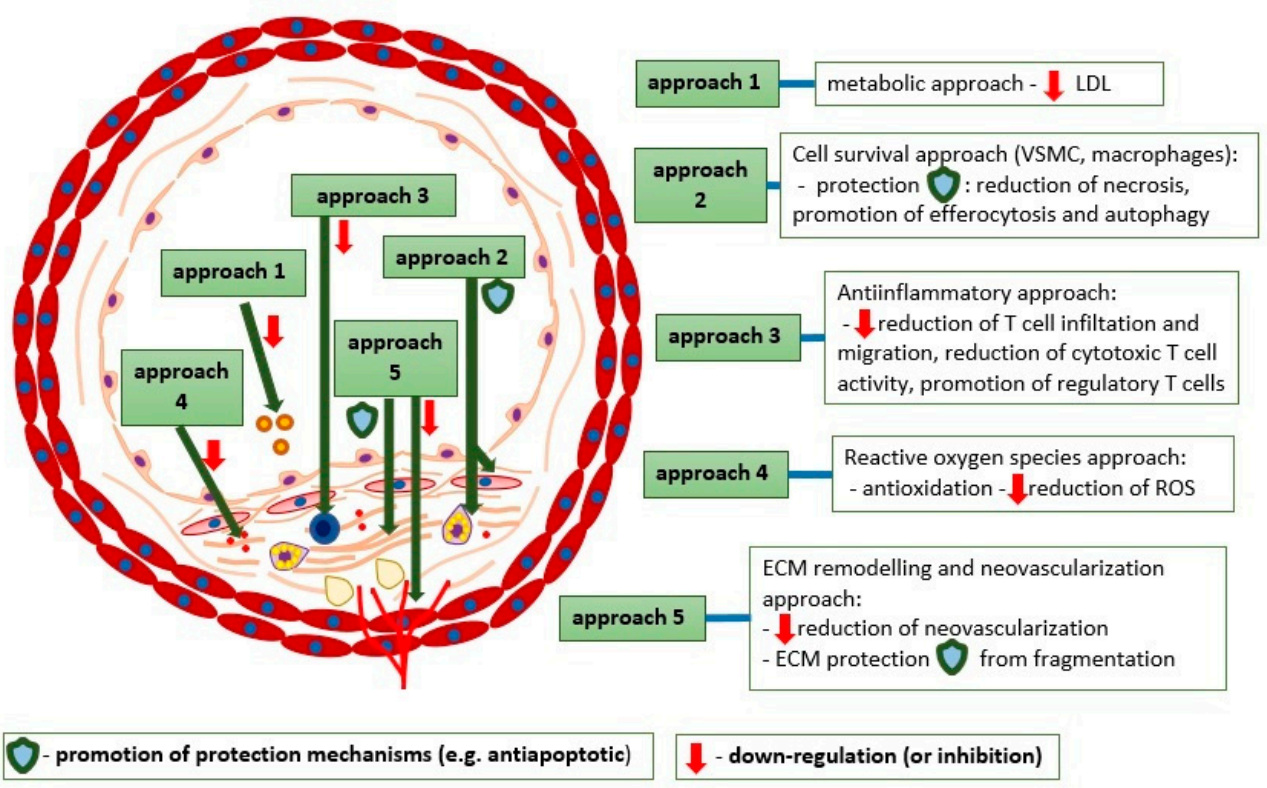

Figure 3. The approaches towards atherosclerotic plaque stabilization therapy and their molecular aspects. 
Many different studies have already been conducted to explore specific approaches towards atherosclerotic plaque destabilization. Some examples of such preclinical studies have been presented in the text; others are presented in Table 1.

Table 1. Examples of atherosclerotic plaque stabilization treatment (five main approaches) in preclinical models and used drugs.

\begin{tabular}{|c|c|c|}
\hline Approaches & Examples and Mechanisms & Investigated Drugs * \\
\hline \multirow{7}{*}{ Metabolic approach } & LDL lowering therapy: & statins (e.g., lovastatin, rosuwastatin, \\
\hline & (a) Targeting HMG-CoA [21]; & atorvastatin, and pitavastatin); \\
\hline & (b) Targeting cholesterol absorption [24]; & ezetimibe; \\
\hline & (c) Enhancing LDL clearance [26]. & PCSK9 inhibitors (alirocumab). \\
\hline & Recombinant HDL particles [28] & $75 \mathrm{mg} / \mathrm{kg}$ of apoA-I(Milano) \\
\hline & $\begin{array}{l}\text { Iron depletion } \rightarrow \text { increased iron mobilization from } \\
\text { macrophages }[88,89]\end{array}$ & Iron chelation therapy (deferasirox) \\
\hline & MGL depletion $\rightarrow$ 2-AG $\uparrow$, CB2R activation [90] & $\begin{array}{l}\text { N/A (genetic knock-out organisms used in this } \\
\text { experiment) }\end{array}$ \\
\hline \multirow{4}{*}{$\begin{array}{l}\text { Cell survival } \\
\text { promotion approach }\end{array}$} & $\begin{array}{l}\text { (a) Promotion of macrophage autophagy [38]; } \\
\text { (b) Efficient efferocytosis of apoptotic bodies } \\
\text { [36]. }\end{array}$ & $\begin{array}{l}\text { (a) trehalose (disaccharide); } \\
\text { (b) AT1R blocker (losartan). }\end{array}$ \\
\hline & $\begin{array}{l}\text { (a) Inhibition of foam cell formation (e.g., LOX-1 } \\
\text { inhibition) [40]; } \\
\text { (b) Inhibition of endopasmatic reticulum (ER) } \\
\text { stress [91]. }\end{array}$ & $\begin{array}{l}\text { (a) Different drugs which caused LOX-1 } \\
\text { inhibition (e.g., Resveratrol, tanshinone II-A, } \\
\text { and berberine); } \\
\text { (b) } \\
\text { 4-phenyl butyric acid (PBA) - a chemical } \\
\text { chaperone). }\end{array}$ \\
\hline & $\begin{array}{l}\text { STAT6 upregulation } \rightarrow \text { M2 macrophage } \\
\text { polarization [92] }\end{array}$ & N/A (overexpression by recombinant pcDNA) \\
\hline & $\begin{array}{l}\text { Prevention from excessive PARP1 activation by } \\
\text { severe DNA damage } \rightarrow \text { prevention from ATP } \\
\text { depletion [93] }\end{array}$ & $\begin{array}{l}\text { For example, 3-Aminobenzamide (3-AB), } \\
\text { doxycycline, thieno(2,3-c)isoquinolin-5-one } \\
\text { (TIQ-A) }\end{array}$ \\
\hline \multirow{4}{*}{$\begin{array}{l}\text { Anti-inflammatory } \\
\text { approach }\end{array}$} & $\begin{array}{l}\text { (a) Chemokine inhibition (e.g., CCL5 and } \\
\text { CXCL10 via TWEAK blockade) [94]; } \\
\text { (b) Cell adhesion molecule (e.g., VCAM-1) } \\
\text { inhibition [95]. }\end{array}$ & $\begin{array}{l}\text { (a) anti-TWEAK mAb, maraviroc (CCR5 } \\
\text { antagonist) [96]; } \\
\text { (b) chalcone derivate }(1 \mathrm{~m}-6)\end{array}$ \\
\hline & $\begin{array}{l}\text { (a) Proinflammatory cytokine (e.g., IL-6, IL-12, } \\
\text { IL-17, IL-18) inhibition }[46,97,98] \text {; } \\
\text { (b) Anti-inflammatory cytokine (such as IL-10, } \\
\text { IL-37) promotion }[55,99] \text {. }\end{array}$ & $\begin{array}{l}\text { (a) For example, IL-6 neutralizing antibody } \\
\text { (toclizumab); } \\
\text { (b) For example, dietary nitrate (L-arginine). }\end{array}$ \\
\hline & Cytotoxic CD8 + T lymphocyte (Tc) depletion [100] & $\mathrm{CD} 8 \alpha$ or $\mathrm{CD} 8 \beta$ targeted monoclonal antibody \\
\hline & Regulatory T lymphocyte (Treg) promotion [101]. & $\begin{array}{l}\text { For example, IL-2, mycophenolate mofetil, vitamin } \\
\text { D, rapamycin, G-CSF }\end{array}$ \\
\hline \multirow{4}{*}{$\begin{array}{l}\text { Reactive oxygen } \\
\text { species approaches }\end{array}$} & $\begin{array}{l}\text { Downregulation of ROS generators (e.g., NADPH } \\
\text { oxidases NOX2) [71] }\end{array}$ & $\begin{array}{l}\text { Nox2 inhibitor peptide (a chimeric } 18 \text {-amino acid } \\
\text { peptide) }\end{array}$ \\
\hline & $\begin{array}{l}\text { Attenuation of ROS derivative (e.g., } 7 \beta-\mathrm{OH}) \\
\text { activity [60]. }\end{array}$ & $\begin{array}{l}\text { N/A (indirect methods like conjugation by } \\
\text { glutathione) }\end{array}$ \\
\hline & $\begin{array}{l}\text { Promotion of ROS scavengers (such as HO-1 } \\
\text { induced by Nrf transcriptional factor) [102] }\end{array}$ & $\mathrm{N} / \mathrm{A}$ \\
\hline & Direct ROS abruption (e.g., polyphenols) [103] & $\begin{array}{l}\text { Different polyphenols (in this study-apple } \\
\text { polyphenols) }\end{array}$ \\
\hline
\end{tabular}


Table 1. Cont

\begin{tabular}{cll}
\hline \multicolumn{1}{c}{ Approaches } & \multicolumn{1}{c}{ Examples and Mechanisms } & \multicolumn{1}{c}{ Investigated Drugs * } \\
\hline & $\begin{array}{l}\text { Inhibition of matrix metalloproteinase (MMPs) } \\
\text { synthesis and activity (especially MMP9) [104] }\end{array}$ & Ghrelin \\
\cline { 2 - 3 } $\begin{array}{c}\text { ECM remodeling and } \\
\text { neovascularization } \\
\text { approach }\end{array}$ & $\begin{array}{l}\text { Promotion of collagen synthesis (e.g., by melatonin } \\
\text { through Akt phosphorylation and subsequent }\end{array}$ & Dietary nitrate treatment $\left(\mathrm{KNO}_{3}{\left.\text { or } \mathrm{KNO}_{2}\right)}^{\mathrm{P} 4 \mathrm{H} \alpha 1 \text { upregulation) [105] }}\right.$ \\
\cline { 2 - 3 } & $\begin{array}{l}\text { Influence on fibronectin (e.g., blockade of } \\
\text { fibronectin-integrin } \alpha 5 \text { pathway) [106] }\end{array}$ & $\begin{array}{l}\text { In vivo knockdown of phosphodiesterase 4D5 } \\
\text { (siRNA) }\end{array}$ \\
\cline { 2 - 3 } & $\begin{array}{l}\text { Inhibition of neovascularization (e.g., through } \\
\text { bFGF blockade) [107] }\end{array}$ & K5 (a small molecule bFGF-inhibitor) \\
\hline
\end{tabular}

Abbreviations: MGL: monoglyceride lipase; 2-AG: 2-arachidonoylglycerol (endocannabinoid); PBA: 4-phenylbutyric acid; mAb: monoclonal antibody. * if applicable (in some studies, transgenic organisms were used to investigate specific cellular pathways).

\section{An Integrated Approach}

Atherosclerotic plaque destabilization is a complex process depending on many different pathways. Therefore, the concept that plaque-stabilizing therapy should target diverse pathways and pathophysiological processes simultaneously is reasonable. For instance, alkaloid berberine has a stabilizing effect on atherosclerotic plaques by the suppression of the ECM regulators MMP9 and EMMPRIN (MMP9 inducer), by autophagy promotion in macrophages, and by promoting antioxidative activity via PPAR $\gamma$ activation (the last effect observed in hyperhomocysteinemia mice) $[108,109]$. In fact, many agents considered primarily as 'specifically targeted' have turned out to be pleiotropic, e.g., lipid-lowering statins or hypoglycemic drugs. As an example, insulin has an anti-inflammatory and plaque-stabilizing effect via the PI3K-Akt pathway, which inhibits the TLR4 MyD88-NF-кB signaling pathway, which was demonstrated using the RAW264.3 monocyte-macrophage lineage [110]. However, the essence of the integrated approach is to target key regulatorstranscription factors or common elements of molecular pathways. Accurate examples are statins that inhibit mevalonic acid synthesis (by HMG-CoA blockade), causing subsequent inhibition of isoprenoid intermediates-farnesyl pyrophosphate (FPP) and geranylgeranyl pyrophosphate (GGPP) synthesis. These isoprenoid intermediates serve as lipid attachments necessary for the appropriate activity of small GTPases, especially Ras and Rho, which regulate many cellular pathways. The Rho protein activates Rho kinases (ROCK), which decrease eNOS synthesis and abolish the atheroprotective PI3K-Akt signaling pathway, whereas Rac1 (a member of the Rho subfamily) activates the nicotinamide adenine dinucleotide phosphate (NADPH) oxidase, which is responsible for reactive oxygen species (ROS) generation. As a result, statins induce anti-inflammatory effects (a decrease in proinflammatory cytokines, e.g., IL-6, IL-8, or MCP-1, and adhesive molecule expression, enhancement of Treg and reduction in Th17 lymphocyte differentiation), ECM stabilizing effects (through matrix metalloproteinases reduction), and antioxidative effects (inhibition of ROS generation) [111,112]. Another example of such an integrative approach is the targeting of lipoprotein-associated phospholipase A2 (Lp-PLA2) by its inhibitor, darapladib. Lp-PLA2 generates lysophosphatidic acid, which increases MMP9 production by the NF- $\mathrm{kB}$ signaling pathway and simultaneously increases plaque inflammation (by mast cell activation and monocyte recruitment), leading to atherosclerotic plaque destabilization $[113,114]$. For this reason, Lp-PLA2 inhibition resulted in plaque stabilization in animal models [115]. The aforementioned approaches are addressed towards proteins that regulate diverse molecular pathways, but there is a different option-targeting epigenetic mechanisms driving gene expression. One such method is the usage of RNA interferenceproteins are translated from their respective mRNA particles, which can be degraded by RISC complexes, composed of microRNA (miRNA) particles complementary to the corresponding mRNAs. MicroRNAs regulate virtually all stages of atherosclerotic plaque progression by downregulation of the corresponding mRNAs [116]. Some miRNA induces 
a stabilizing effect on the plaque structure, for instance, miR-520c-3p-a downregulator of RelA/p65 (NF-кB subunit) or miR 181b-5p-a downregulator of NOTCH1 (a promoter of proinflammatory M1 macrophages) $[117,118]$. In contrast, an example of destabilizing miRNA is miR-124-3p [31,119]. Therefore, an application of agonists (agomirs) of stabilizing miRNAs or antagonists (antagomirs) of destabilizing miRNAs could prevent plaque vulnerability [120]. However, there is another method of an integrative approach promoting atherosclerotic plaque stability - the influence on gene expression through changes in chromatin compaction. DNA strands are wrapped onto nucleosomes built up from histones. Histone acetylation (performed by HATs-histone acetyltransferases) and histone deacetylation (performed by HDACs-histone deacetylases) regulate gene expression making them more or less accessible to RNA polymerase [121]. For instance, HDAC9 increases MMP-1 and MMP-2 expression and toll-like receptor (TLR) signaling at the histone level, and its deficiency or blockade results in inflammation resolution and plaque stabilization [122]. Sirtuins are regulators which also act as histone deacetylases. For example, SIRT2 exerts plaque-stabilizing effects by the inhibition of macrophage polarization towards the M1 phenotype and reduction in iNOS activity. These effects can be induced by Resveratrol, a SIRT2 agonist $[123,124]$. In summary, an integrative approach (the concept illustrated in Figure 4) makes it possible to have a wide range of effects upon the entire plaque and change its phenotype.

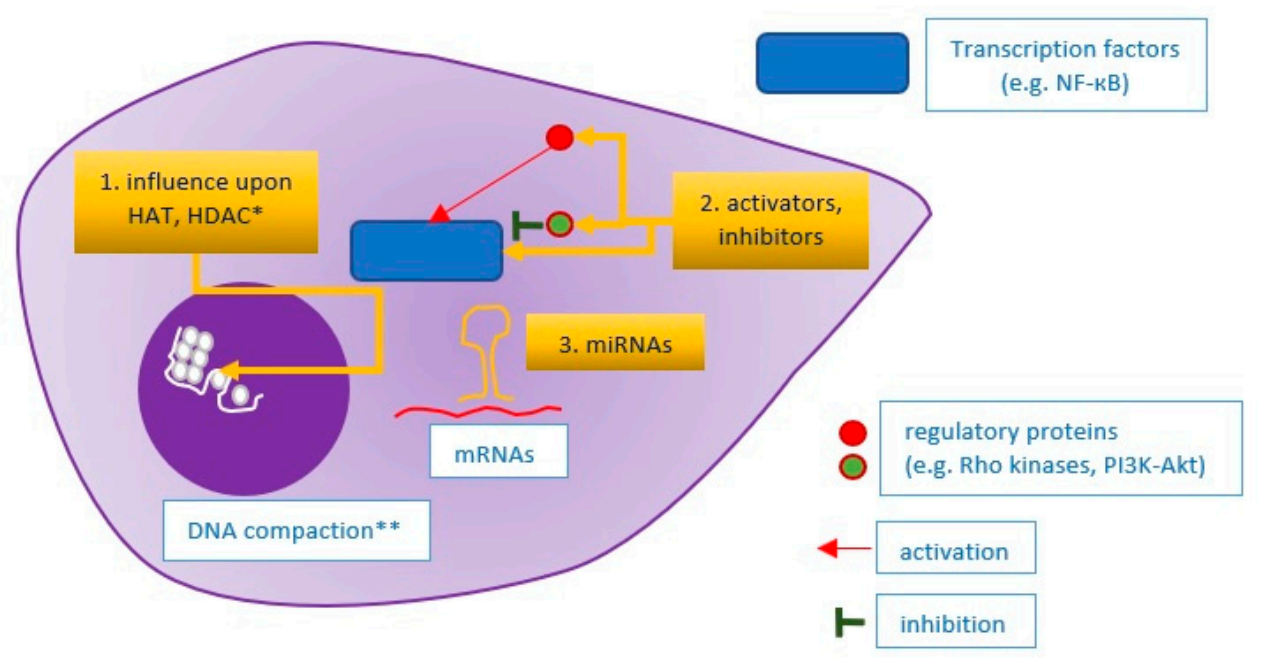

Figure 4. Idea of an integrative approach towards atherosclerotic plaque stabilization. 1. Influence upon mechanisms that are responsible for chromatin compaction and DNA accessibility for transcription machinery; 2 . Activation or inhibition of transcription factors, regulating gene expression in the nucleus; 3. Influence upon miRNAs, i.e., particles that inhibit specific mRNA particles in the mechanism of complementarity. * HAT: histone acetyltransferase; HDAC: histone deacetylase; ** DNA compaction relies on nucleosome methylation or acetylation (regulated by HATs and HDACs).

\section{Clinical Studies Conforming Plaque Stabilization}

Numerous preclinical studies have confirmed the plaque-stabilizing effect of different approaches (as mentioned above). However, the promising results of studies on animal models have not been reflected in human clinical studies. There are several explanations for this, i.e., differences in the pathophysiological process of atherosclerotic plaque destabilization (guided by different genes) and in cellular subsets (such as the macrophage population) between laboratory animals and humans, different experimental conditions, and natural diversities in the human population [125-127]. Large clinical studies on medicines in the therapy of atherosclerosis particularly concentrate on clinical endpoints-especially mortality, mortality due to cardiovascular reasons, and MACE (a composite endpoint composed of mortality, myocardial infarction, stroke). From this point of view, a canakinumab (antiIL-1 $\beta$ antibody) given to patients with a previous myocardial infarction (CANTOS study) caused a significant reduction in recurrent cardiovascular events (a dose of $150 \mathrm{mg}$ once 
a month, relative risk $0.85 ; 95 \% \mathrm{CI}, 0.74$ to $0.98, p=0.021)$ compared with a placebo [128]. Similarly, colchicine ( $0.5 \mathrm{mg}$ a day) given to patients after a myocardial infarction caused a significant reduction in composite endpoint (RR $0.77 ; 95 \% \mathrm{CI}, 0.61$ to $0.96, p=0.02$ ) and a marked significant reduction in recurrent myocardial infarction (RR 0.26 ; 95\%CI, 0.1 to 0.7) in comparison with a placebo, which was demonstrated in the COLCOT study [129]. In contrast, a study called STABILITY with darapladib conducted on patients with stable coronary artery disease (without prior myocardial infarction) failed to demonstrate a statistical significance between the darapladib and placebo groups in reference to composite endpoint and mortality, although it showed a slight but significant reduction in major coronary events $(9.3 \%$ vs. 10.3\%, $p=0.045)$ [130]. Similarly, the CETP inhibitor anacetrapib causing an HDL increase demonstrated a slight but significant reduction in major coronary events (REVEAL study) [131]. However, to verify whether a certain type of therapy results in atherosclerotic plaque stabilization, it is necessary to visualize the plaques in the coronary arteries and assess their stability exponents. Methods that enable such visualization are intravascular ultrasound (IVUS) and OCT (optical coherence tomography). Studies in which atherosclerotic plaques were assessed in the light of stability are presented in Table 2 [132].

Table 2. Clinical studies with outcomes referring to atherosclerotic plaque stabilization visualized with imaging methods (IVUS or OCT).

\begin{tabular}{|c|c|c|c|c|}
\hline STUDY NAME & Treatment & $\begin{array}{l}\text { No. of Investigated } \\
\text { Patients } \\
\text { (Period) }\end{array}$ & $\begin{array}{l}\text { Clinical Outcome } \\
\text { (MACE, Mortality) }\end{array}$ & $\begin{array}{c}\text { Plaque Stabilization Effect (IVUS } \\
\text { or OCT) }\end{array}$ \\
\hline GAIN [133] ${ }^{1}$ & $\begin{array}{c}\text { Atorvastatin }(\mathbf{2 0}-\mathbf{8 0} \mathbf{~ m g}) \\
\text { vs. } \\
\text { placebo }\end{array}$ & $\begin{array}{l}65 \text { and } 66 \\
\text { (12 months) }\end{array}$ & $\begin{array}{l}\text { Any ischemic event: } \\
\mathbf{2 1 . 5 \%} \text { vs. } 31.8 \% \\
(p=0.184)\end{array}$ & $\begin{array}{l}\text { IVUS: Larger hyperechogenicity } \\
\text { index } 42.2 \% \text { vs. } 10.1 \% \\
p=0.021\end{array}$ \\
\hline $\begin{array}{l}\text { REVERSAL } \\
\text { [134] }^{2}\end{array}$ & $\begin{array}{c}\text { Atorvastatin } 80 \text { mg (intensive } \\
\text { lipid-lowering) } \\
\text { vs. } \\
\text { Pravastatin } 40 \mathrm{mg} \text { (moderate } \\
\text { lipid-lowering) }\end{array}$ & $\begin{array}{l}253 \text { and } 249 \\
(18 \text { months })\end{array}$ & $\begin{array}{c}\text { Death: } \\
0.3 \% \text { vs. } 0.3 \%-\mathrm{NS} \\
\text { Myocardial infarction: } \\
1.2 \% \text { vs. } 2.1 \%-\mathrm{NS}\end{array}$ & $\begin{array}{l}\text { IVUS: Lower percent atheroma } \\
\text { volume change } 0.2 \% \text { vs. } 1.6 \% \text {, } \\
\qquad p<0.001\end{array}$ \\
\hline $\begin{array}{l}\text { PRECISE- } \\
\text { IVUS [37] } \\
\qquad 3\end{array}$ & $\begin{array}{l}\text { Atorvastatin * + ezetimibe } \\
\qquad(10 \mathrm{mg}) \\
\text { vs. } \\
\text { Atorvastatin * alone }\end{array}$ & $\begin{array}{l}102 \text { and } 100 \\
\text { (9-12 months) }\end{array}$ & $\begin{array}{l}\text { Cardiovascular events ** } \\
11 \% \text { vs. } 14 \%-\mathrm{NS}\end{array}$ & $\begin{array}{c}\text { IVUS: Change in normalized TAV } \\
-6.6 \% \text { vs. }-1.4 \% \\
p<0.001\end{array}$ \\
\hline$\underset{\mathbf{4}}{\operatorname{GLAGOV}[135]}$ & $\begin{array}{c}\text { Statin } * * *+\text { PCSK9i } \\
\text { (evolocumab } 420 \mathrm{mg} \\
\text { monthly) } \\
\text { vs. } \\
\text { Statin }{ }^{* * *} \text { alone }\end{array}$ & $\begin{array}{l}423 \text { and } 423 \\
\text { (19 months) }\end{array}$ & $\begin{array}{c}\text { Death: } \\
\mathbf{0 . 6 \%} \text { vs. } 0.8 \%-\mathrm{NS} \\
\text { Non-fatal myocardial } \\
\text { infarction: } \\
\mathbf{2 . 1 \%} \text { vs } 2.9 \%-\mathrm{NS}\end{array}$ & $\begin{array}{c}\text { IVUS: Change in TAV } \\
-\mathbf{5 . 8 \%} \text { vs. }-0.9 \% \\
p<0.001\end{array}$ \\
\hline $\begin{array}{l}\text { Christoph et al. } \\
\text { [136] }\end{array}$ & $\begin{array}{c}\text { Pioglitazone ( } 30 \mathrm{mg}) \\
\text { vs. } \\
\text { Placebo }\end{array}$ & $\begin{array}{l}27 \text { and } 27 \\
\text { (9 months) }\end{array}$ & $\begin{array}{l}\text { Insignificant differences, } \\
\text { no MACE registered }\end{array}$ & $\begin{array}{l}\text { VH-IVUS: Decrease in the necrotic } \\
\text { core } \\
\mathbf{- 1 . 3 \%} \text { vs. }+2.6 \% \\
p=0.008\end{array}$ \\
\hline $\begin{array}{c}\text { Tondapu et al. } \\
\text { [137] }\end{array}$ & $\begin{array}{l}\text { Rosuvastatin (10 mg) } \\
\text { vs. } \\
\text { Atorvastatin }(20 \mathrm{mg})\end{array}$ & $\begin{array}{l}24 \text { and } 19 \\
(12 \text { months })\end{array}$ & Not applicable & $\begin{array}{c}\text { OCT: } \\
\text { Increased FCT ****} \\
\mathbf{1 7 1 . 5} \text { vs. } 127.0 \mu \mathrm{m} \\
p=0.03 \\
\text { Decreased macrophages }\end{array}$ \\
\hline
\end{tabular}

${ }^{1}$ German Atorvastatin Intravascular Ultrasound Study Investigators; ${ }^{2}$ Reversal of Atherosclerosis with Aggressive Lipid Lowering Study; ${ }^{3}$ Plaque Regression With Cholesterol Absorption Inhibitor or Synthesis Inhibitor Evaluated by Intravascular Ultrasound; ${ }^{4}$ Global Assessment of Plaque Regression With a PCSK9 Antibody as Measured by Intravascular Ultrasound. * Atorvastatin dose adequate for efficient lipid-lowering with target LDL $<70 \mathrm{mg} / \mathrm{dL}$; ${ }^{* *}$ Cardiovascular events-mainly revascularizations of de novo lesions, no cases of death during follow-up in this study; ${ }^{* *}$ Statin dose adequate for efficient lipid lowering with target LDL $<80 \mathrm{mg} / \mathrm{dL}$ (or $<60 \mathrm{mg} / \mathrm{dL}$, in case of additional risk factors); ${ }^{* * *}$ similar baseline fibrous cap thickness in both groups $(61.4 \mu \mathrm{m}$ in rosuvastatin group and $60.8 \mu \mathrm{m}$ in atorvastatin group); IVUS: intravascular ultrasound; VH-IVUS: virtual histology-intravascular ultrasound; OCT: optical coherence tomography; TAV: total atheroma volume; FCT: fibrous cap thickness. 


\section{Alternative Approaches}

This review so far has presented approaches towards atherosclerotic plaque stabilization directed at general mechanisms - the enhancement of stabilizing pathways and the inhibition of destabilizing pathways. In this section, alternative approaches are discussed. As presented above, stable and vulnerable atherosclerotic plaques can transform into one another [15]. Nevertheless, approaches towards the stabilization of concrete and already developed unstable plaque are also under investigation. Examples of such therapies are photodynamic therapy (PDT), plasmonic photothermal therapy (PPTT), cytotoxic chemotherapy, and sonodynamic therapy (SDT) $[16,138]$. In PDT, administered photosensitizers accumulate within the atherosclerotic plaque (e.g., cross-linked dextran-coated iron oxide (CLIO) nanoparticles which accumulate in macrophages). Then, irradiation of the structure by NIR (near-infrared) causes free radical generation and a cytotoxic effect upon the macrophages (mainly from the M1 subset, dominating in a vulnerable structure), resulting in plaque stabilization. PPTT is quite similar to PDT, but in this method, photoabsorbers (e.g., gold nanoparticles) generate heat when irradiated by NIR. In cytotoxic chemotherapy, special agents are encapsulated in nanomedical liposomes (e.g., prednisolone phosphate) or other formulas such as hyaluronic acid-polypyrrole nanoparticles (e.g., doxorubicin), which make it possible for them to accumulate precisely within the plaque and exert their action. Finally, SDT compounds called sonosensitizers (such as curcumin) localize within the plaque and generate free radicals after exposure to ultrasound. Therefore, SDT is similar to PDT, but ultrasound waves penetrate more deeply than NIR. The principles of the abovementioned methods are illustrated in Figure 5.

Some clinical trials using the abovementioned methods in the therapy of atherosclerotic plaque have already been undertaken [139]. For instance, the NANOM-FIM trial has demonstrated that a group of patients who received silica-gold nanoparticles with subsequent PPTT presented a significantly higher probability of event-free survival than the control group $(91.7 \%$ vs. $80 \%$ ) who only received a drug-eluting stent [140]. Moreover, new discoveries such as quantum dots may enable high precision therapy with pre-selected cells introduced into the plaque [141].

In the discussion about approaches towards atherosclerotic plaque stabilization, it must be said that there is also a totally different option-not concentrating on plaque stabilization but rather on the minimization of the consequences of a plaque rupture. The idea of this approach is based on the hypothesis that it is difficult to precisely distinguish between stable and vulnerable atherosclerotic plaque, and microruptures or erosions might occur in many plaques considered to be stable. From that point of view, antithrombotic therapy could be crucial for the prevention of major cardiovascular events such as myocardial infarction because it inhibits clot generation and coronary artery obstruction in the case of a vulnerable plaque rupture or erosion [142]. Although aspirin (a 'classical' antithrombotic drug) has turned out to be beneficial in the primary prevention of myocardial infarction (ATT meta-analysis, $12 \%$ proportional reduction in serious cardiovascular events per year, $p=0.0001$ ), it significantly increased the risk of major gastrointestinal and intracranial bleeding [143]. Therefore, the guidelines (similar to many ESC guidelines) consider aspirin to be a tool for secondary, but not primary, prevention of myocardial infarction.

Finally, approaches towards some pathways in atherosclerotic plaque destabilization still remain controversial, such as targeting pathways involved in plaque calcification (regulated by, for example, oncostatin M). Currently, it is supposed that although plaque macrocalcifications (as in fibrocalcific plaque) increase plaque stability, microcalcifications tend to destabilize the plaque [144]. 

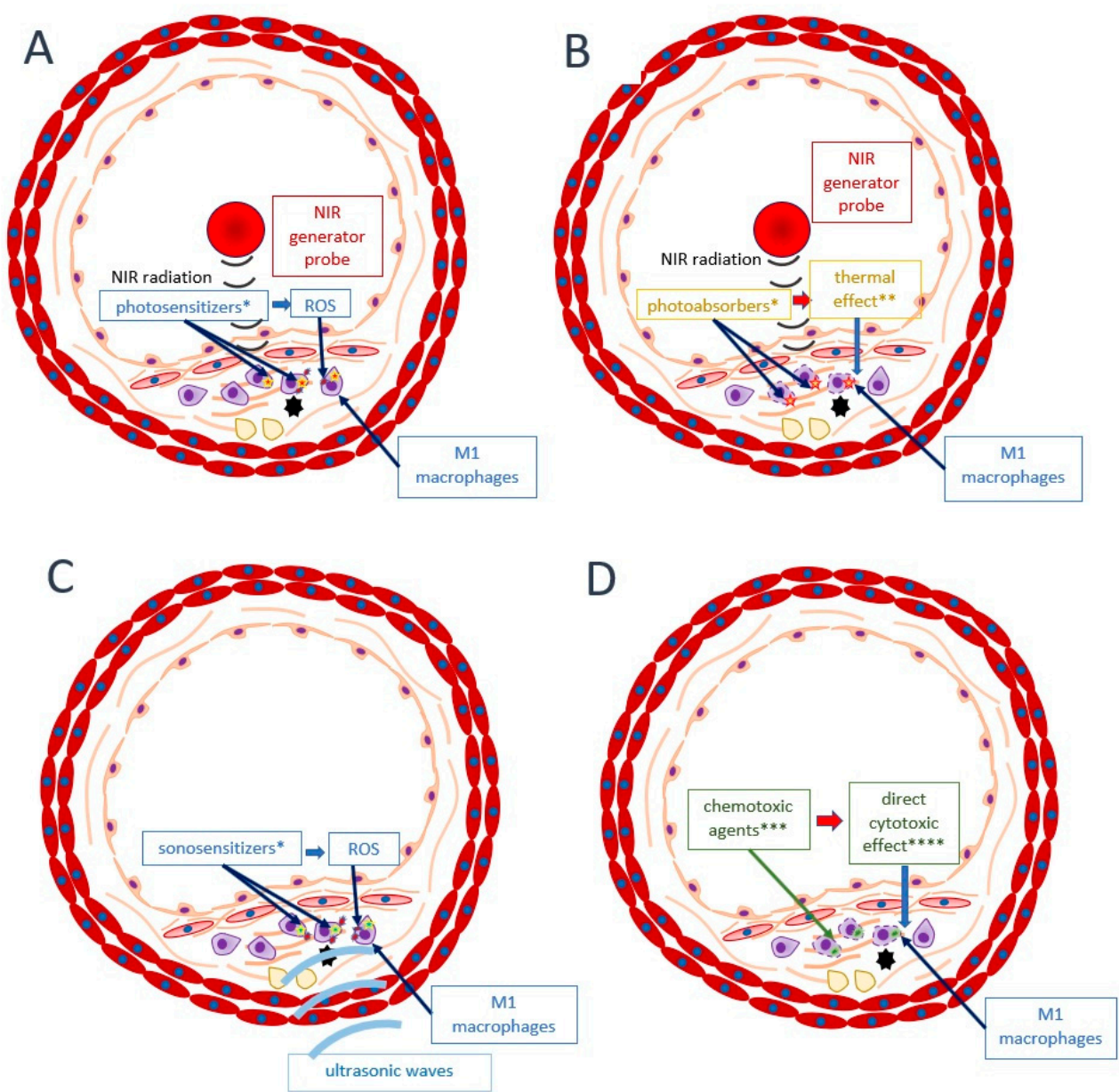

Figure 5. Alternative approaches towards atherosclerotic plaque stabilization targeted at concretely already developed vulnerable plaques. (A) photodynamic therapy (PDT); (B) plasmonic photothermal therapy (PPTT); (C) sonodynamic therapy; (D) cytotoxic chemotherapy. * photosensitizer, photoabsorber, or sonosensitizer previously injected into the organism, then accumulated within plaque macrophages; ${ }^{* *}$ effects inducing apoptosis or other forms of cellular death; *** chemotoxic agents encapsulated in nanoformulas and targeted specifically to macrophages; ${ }^{* * *}$ apoptosis, necrosis, necroptosis. ROS: reactive oxygen species; NIR: near-infrared.

\section{Conclusions}

In summary, atherosclerotic plaque stabilization is a promising therapy for the reduction in cardiovascular disease burden. Although many interesting discoveries and approaches have already been discovered, there is still a lack of clinically proven methods that enable maintaining the stability of virtually all of the atherosclerotic plaques in a patient. Moreover, many aspects of plaque vulnerability are still controversial and are waiting for a more profound explanation.

Author Contributions: Conceptualization, M.K. and A.C.-J.; resources, M.K. and A.C.-J.; writing M.K.; supervision, A.C.-J. All authors have read and agreed to the published version of the manuscript.

Funding: This research received no external funding.

Conflicts of Interest: The authors declare no conflict of interest.

\section{References}

1. Malakar, A.K.; Choudhury, D.; Halder, B.; Paul, P.; Uddin, A.; Chakraborty, S. A review on coronary artery disease, its risk factors, and therapeutics. J. Cell. Physiol. 2019, 234, 16812-16823. [CrossRef] [PubMed]

2. Reed, G.W.; Rossi, J.E.; Cannon, C.P. Acute myocardial infarction. Lancet 2017, 389, 197-210. [CrossRef]

3. Frangogiannis, N.G. Pathophysiology of Myocardial Infarction. Compr. Physiol. 2015, 5, 1841-1875. [PubMed] 
4. Tibaut, M.; Mekis, D.; Petrovic, D. Pathophysiology of Myocardial Infarction and Acute Management Strategies. Cardiovasc. Hematol. Agents Med. Chem. 2017, 14, 150-159. [CrossRef] [PubMed]

5. Kumar, A.; Cannon, C.P. Acute coronary syndromes: Diagnosis and management, part I. Mayo Clin. Proc. 2009, 84, 917-938. [CrossRef] [PubMed]

6. Aufderheide, T.P. Arrhythmias associated with acute myocardial infarction and thrombolysis. Emerg. Med. Clin. N. Am. 1998, 16, 583-600. [CrossRef]

7. Saleh, M.; Ambrose, J.A. Understanding myocardial infarction. F1000Research 2018, 7, 1378. [CrossRef] [PubMed]

8. Bentzon, J.F.; Otsuka, F.; Virmani, R.; Falk, E. Mechanisms of plaque formation and rupture. Circ. Res. 2014, 114, 1852-1866. [CrossRef] [PubMed]

9. Tabas, I.; Garcia-Cardena, G.; Owens, G.K. Recent insights into the cellular biology of atherosclerosis. J. Cell Biol. 2015, 209, 13-22. [CrossRef]

10. Geovanini, G.R.; Libby, P. Atherosclerosis and inflammation: Overview and updates. Clin. Sci. 2018, 132, 1243-1252. [CrossRef]

11. Khan, M.H.; Rochlani, Y.; Yandrapalli, S.; Aronow, W.S.; Frishman, W.H. Vulnerable Plaque: A Review of Current Concepts in Pathophysiology and Imaging. Cardiol. Rev. 2020, 28, 3-9. [CrossRef] [PubMed]

12. Virmani, R.; Burke, A.P.; Farb, A.; Kolodgie, F.D. Pathology of the vulnerable plaque. J. Am. Coll. Cardiol. 2006, 47 (Suppl. 8), C13-C18. [CrossRef]

13. Silvestre-Roig, C.; de Winther, M.P.; Weber, C.; Daemen, M.J.; Lutgens, E.; Soehnlein, O. Atherosclerotic plaque destabilization: Mechanisms, models, and therapeutic strategies. Circ. Res. 2014, 114, 214-226. [CrossRef]

14. Stone, G.W.; Maehara, A.; Lansky, A.J.; de Bruyne, B.; Cristea, E.; Mintz, G.S.; Mehran, R.; McPherson, J.; Farhat, N.; Marso, S.P.; et al. A prospective natural-history study of coronary atherosclerosis. N. Engl. J. Med. 2011, 364, 226-235. [CrossRef]

15. Arbab-Zadeh, A.; Fuster, V. The myth of the "vulnerable plaque": Transitioning from a focus on individual lesions to atherosclerotic disease burden for coronary artery disease risk assessment. J. Am. Coll. Cardiol. 2015, 65, 846-855. [CrossRef]

16. Zhang, Y.; Koradia, A.; Kamato, D.; Popat, A.; Little, P.J.; Ta, H.T. Treatment of atherosclerotic plaque: Perspectives on theranostics. J. Pharm. Pharmacol. 2019, 71, 1029-1043. [CrossRef] [PubMed]

17. Yuan, R.; Shi, W.L.; Xin, Q.Q.; Chen, K.J.; Cong, W.H. Holistic Regulation of Angiogenesis with Chinese Herbal Medicines as a New Option for Coronary Artery Disease. Evid. Based Complement. Alternat. Med. 2018, 2018, 3725962. [CrossRef]

18. Song, G.; Tian, H.; Qin, S.; Sun, X.; Yao, S.; Zong, C.; Luo, Y.; Liu, J.; Yu, Y.; Sang, H.; et al. Hydrogen decreases atherosusceptibility in apolipoprotein B-containing lipoproteins and aorta of apolipoprotein E knockout mice. Atherosclerosis 2012, 221, 55-65. [CrossRef] [PubMed]

19. Tuttolomondo, A.; Simonetta, I.; Daidone, M.; Mogavero, A.; Ortello, A.; Pinto, A. Metabolic and Vascular Effect of the Mediterranean Diet. Int. J. Mol. Sci. 2019, 20, 4716. [CrossRef]

20. Veseli, B.E.; Perrotta, P.; De Meyer, G.R.A.; Roth, L.; Van der Donckt, C.; Martinet, W.; De Meyer, G.R.Y. Animal models of atherosclerosis. Eur. J. Pharmacol. 2017, 816, 3-13. [CrossRef]

21. Shiomi, M.; Koike, T.; Ito, T. Contribution of the WHHL rabbit, an animal model of familial hypercholesterolemia, to elucidation of the anti-atherosclerotic effects of statins. Atherosclerosis 2013, 231, 39-47. [CrossRef]

22. Hartwig, H.; Silvestre-Roig, C.; Hendrikse, J.; Beckers, L.; Paulin, N.; Van der Heiden, K.; Braster, Q.; Drechsler, M.; Daemen, M.J.; Lutgens, E.; et al. Atherosclerotic Plaque Destabilization in Mice: A Comparative Study. PLoS ONE 2015, 10, e0141019. [CrossRef]

23. Jain, M.; Frobert, A.; Valentin, J.; Cook, S.; Giraud, M.N. The Rabbit Model of Accelerated Atherosclerosis: A Methodological Perspective of the Iliac Artery Balloon Injury. J. Vis. Exp. 2017. [CrossRef]

24. Gomez-Garre, D.; Munoz-Pacheco, P.; Gonzalez-Rubio, M.L.; Aragoncillo, P.; Granados, R.; Fernandez-Cruz, A. Ezetimibe reduces plaque inflammation in a rabbit model of atherosclerosis and inhibits monocyte migration in addition to its lipid-lowering effect. Br. J. Pharmacol. 2009, 156, 1218-1227. [CrossRef] [PubMed]

25. Muller-Wieland, D.; Kotzka, J.; Krone, W. Stabilization of atherosclerotic plaque during lipid lowering. Curr. Opin. Lipidol. 1997, 8, 348-353. [CrossRef]

26. Kuhnast, S.; van der Hoorn, J.W.; Pieterman, E.J.; van den Hoek, A.M.; Sasiela, W.J.; Gusarova, V.; Peyman, A.; Schafer, H.L.; Schwahn, U.; Jukema, J.W.; et al. Alirocumab inhibits atherosclerosis, improves the plaque morphology, and enhances the effects of a statin. J. Lipid Res. 2014, 55, 2103-2112. [CrossRef] [PubMed]

27. Ouimet, M.; Barrett, T.J.; Fisher, E.A. HDL and Reverse Cholesterol Transport. Circ. Res. 2019, 124, 1505-1518. [CrossRef]

28. Ibanez, B.; Giannarelli, C.; Cimmino, G.; Santos-Gallego, C.G.; Alique, M.; Pinero, A.; Vilahur, G.; Fuster, V.; Badimon, L.; Badimon, J.J. Recombinant HDL(Milano) exerts greater anti-inflammatory and plaque stabilizing properties than HDL(wild-type). Atherosclerosis 2012, 220, 72-77. [CrossRef] [PubMed]

29. Kuhnast, S.; van der Tuin, S.J.; van der Hoorn, J.W.; van Klinken, J.B.; Simic, B.; Pieterman, E.; Havekes, L.M.; Landmesser, U.; Luscher, T.F.; Willems van Dijk, K.; et al. Anacetrapib reduces progression of atherosclerosis, mainly by reducing non-HDLcholesterol, improves lesion stability and adds to the beneficial effects of atorvastatin. Eur. Heart J. 2015, 36, 39-48. [CrossRef] [PubMed]

30. Van Craeyveld, E.; Gordts, S.C.; Nefyodova, E.; Jacobs, F.; De Geest, B. Regression and stabilization of advanced murine atherosclerotic lesions: A comparison of LDL lowering and HDL raising gene transfer strategies. J. Mol. Med. 2011, 89, 555-567. [CrossRef] [PubMed] 
31. Liang, W.J.; Zhou, S.N.; Shan, M.R.; Wang, X.Q.; Zhang, M.; Chen, Y.; Zhang, Y.; Wang, S.X.; Guo, T. AMPKalpha inactivation destabilizes atherosclerotic plaque in streptozotocin-induced diabetic mice through AP-2alpha/miRNA-124 axis. J. Mol. Med. 2018, 96, 403-412. [CrossRef] [PubMed]

32. Barrett, T.J. Macrophages in Atherosclerosis Regression. Arterioscler. Thromb. Vasc. Biol. 2020, 40, 20-33. [CrossRef]

33. Kavurma, M.M.; Rayner, K.J.; Karunakaran, D. The walking dead: Macrophage inflammation and death in atherosclerosis. Curr. Opin. Lipidol. 2017, 28, 91-98. [CrossRef] [PubMed]

34. Babaev, V.R.; Yeung, M.; Erbay, E.; Ding, L.; Zhang, Y.; May, J.M.; Fazio, S.; Hotamisligil, G.S.; Linton, M.F. Jnk1 Deficiency in Hematopoietic Cells Suppresses Macrophage Apoptosis and Increases Atherosclerosis in Low-Density Lipoprotein Receptor Null Mice. Arterioscler. Thromb. Vasc. Biol. 2016, 36, 1122-1131. [CrossRef]

35. Linton, M.F.; Tao, H.; Linton, E.F.; Yancey, P.G. SR-BI: A Multifunctional Receptor in Cholesterol Homeostasis and Atherosclerosis. Trends Endocrinol. Metab. 2017, 28, 461-472. [CrossRef]

36. Evans, T.D.; Jeong, S.J.; Zhang, X.; Sergin, I.; Razani, B. TFEB and trehalose drive the macrophage autophagy-lysosome system to protect against atherosclerosis. Autophagy 2018, 14, 724-726. [CrossRef]

37. Abderrazak, A.; Couchie, D.; Mahmood, D.F.; Elhage, R.; Vindis, C.; Laffargue, M.; Mateo, V.; Buchele, B.; Ayala, M.R.; El Gaafary, M.; et al. Anti-inflammatory and antiatherogenic effects of the NLRP3 inflammasome inhibitor arglabin in ApoE2.Ki mice fed a high-fat diet. Circulation 2015, 131, 1061-1070. [CrossRef]

38. Zhang, Y.; Wang, Y.; Zhou, D.; Zhang, L.S.; Deng, F.X.; Shu, S.; Wang, L.J.; Wu, Y.; Guo, N.; Zhou, J.; et al. Angiotensin II deteriorates advanced atherosclerosis by promoting MerTK cleavage and impairing efferocytosis through the AT1R/ROS/p38 MAPK/ADAM17 pathway. Am. J. Physiol. Cell Physiol. 2019, 317, C776-C787. [CrossRef] [PubMed]

39. Feldmann, R.; Geikowski, A.; Weidner, C.; Witzke, A.; Kodelja, V.; Schwarz, T.; Gabriel, M.; Erker, T.; Sauer, S. Foam cell specific LXRalpha ligand. PLoS ONE 2013, 8, e57311. [CrossRef] [PubMed]

40. Kattoor, A.J.; Goel, A.; Mehta, J.L. LOX-1: Regulation, Signaling and Its Role in Atherosclerosis. Antioxidants 2019, 8, 218. [CrossRef] [PubMed]

41. Tian, K.; Ogura, S.; Little, P.J.; Xu, S.W.; Sawamura, T. Targeting LOX-1 in atherosclerosis and vasculopathy: Current knowledge and future perspectives. Ann. N. Y. Acad. Sci. 2019, 1443, 34-53. [CrossRef] [PubMed]

42. Weber, C.; Noels, H. Atherosclerosis: Current pathogenesis and therapeutic options. Nat. Med. 2011, 17, 1410-1422. [CrossRef]

43. Wolf, M.P.; Hunziker, P. Atherosclerosis: Insights into Vascular Pathobiology and Outlook to Novel Treatments. J. Cardiovasc. Transl. Res. 2020, 13, 744-757. [CrossRef]

44. van Dijk, R.A.; Duinisveld, A.J.; Schaapherder, A.F.; Mulder-Stapel, A.; Hamming, J.F.; Kuiper, J.; de Boer, O.J.; van der Wal, A.C.; Kolodgie, F.D.; V irmani, R.; et al. A change in inflammatory footprint precedes plaque instability: A systematic evaluation of cellular aspects of the adaptive immune response in human atherosclerosis. J. Am. Heart Assoc. 2015, 4, e001403. [CrossRef] [PubMed]

45. Sliva, J.; Charalambous, C.; Bultas, J.; Karetova, D. A new strategy for the treatment of atherothrombosis-Inhibition of inflammation. Physiol. Res. 2019, 68 (Suppl. 1), S17-S30. [CrossRef] [PubMed]

46. Janssen, H.; Wagner, C.S.; Demmer, P.; Callies, S.; Solter, G.; Loghmani-khouzani, H.; Hu, N.; Schuett, H.; Tietge, U.J.; Warnecke, G.; et al. Acute perioperative-stress-induced increase of atherosclerotic plaque volume and vulnerability to rupture in apolipoproteinE-deficient mice is amenable to statin treatment and IL-6 inhibition. Dis. Model Mech. 2015, 8, 1071-1080. [CrossRef] [PubMed]

47. Segers, D.; Lipton, J.A.; Leenen, P.J.; Cheng, C.; Tempel, D.; Pasterkamp, G.; Moll, F.L.; de Crom, R.; Krams, R. Atherosclerotic Plaque Stability Is Affected by the Chemokine CXCL10 in Both Mice and Humans. Int. J. Inflam. 2011, 2011, 936109. [CrossRef]

48. Gomez, D.; Baylis, R.A.; Durgin, B.G.; Newman, A.A.C.; Alencar, G.F.; Mahan, S.; St Hilaire, C.; Muller, W.; Waisman, A.; Francis, S.E.; et al. Interleukin-1beta has atheroprotective effects in advanced atherosclerotic lesions of mice. Nat. Med. 2018, 24, 1418-1429. [CrossRef]

49. Bhaskar, V.; Yin, J.; Mirza, A.M.; Phan, D.; Vanegas, S.; Issafras, H.; Michelson, K.; Hunter, J.J.; Kantak, S.S. Monoclonal antibodies targeting IL-1 beta reduce biomarkers of atherosclerosis in vitro and inhibit atherosclerotic plaque formation in Apolipoprotein E-deficient mice. Atherosclerosis 2011, 216, 313-320. [CrossRef] [PubMed]

50. Spartalis, M.; Spartalis, E.; Tzatzaki, E.; Tsilimigras, D.I.; Moris, D.; Kontogiannis, C.; Kaminiotis, V.V.; Paschou, S.A.; Chatzidou, S.; Siasos, G.; et al. The Beneficial Therapy with Colchicine for Atherosclerosis via Anti-inflammation and Decrease in Hypertriglyceridemia. Cardiovasc. Hematol. Agents Med. Chem. 2018, 16, 74-80. [CrossRef] [PubMed]

51. Cecconi, A.; Vilchez-Tschischke, J.P.; Mateo, J.; Sanchez-Gonzalez, J.; Espana, S.; Fernandez-Jimenez, R.; Lopez-Melgar, B.; Fernandez Friera, L.; Lopez-Martin, G.J.; Fuster, V.; et al. Effects of Colchicine on Atherosclerotic Plaque Stabilization: A Multimodality Imaging Study in an Animal Model. J. Cardiovasc. Transl. Res. 2020, 14, 150-160. [CrossRef]

52. Aguilar, E.C.; Leonel, A.J.; Teixeira, L.G.; Silva, A.R.; Silva, J.F.; Pelaez, J.M.; Capettini, L.S.; Lemos, V.S.; Santos, R.A.; Alvarez-Leite, J.I. Butyrate impairs atherogenesis by reducing plaque inflammation and vulnerability and decreasing NFkappaB activation. Nutr. Metab. Cardiovasc. Dis. 2014, 24, 606-613. [CrossRef] [PubMed]

53. Zhao, D.; Tong, L.; Zhang, L.; Li, H.; Wan, Y.; Zhang, T. Tanshinone II A stabilizes vulnerable plaques by suppressing RAGE signaling and NF-kappaB activation in apolipoprotein-E-deficient mice. Mol. Med. Rep. 2016, 14, 4983-4990. [CrossRef] [PubMed]

54. Shen, L.; Sun, Z.; Nie, P.; Yuan, R.; Cai, Z.; Wu, C.; Hu, L.; Jin, S.; Zhou, H.; Zhang, X.; et al. Sulindac-derived retinoid X receptor-alpha modulator attenuates atherosclerotic plaque progression and destabilization in ApoE(-/-) mice. Br. J. Pharmacol. 2019, 176, 2559-2572. [CrossRef] 
55. Liu, J.; Lin, J.; He, S.; Wu, C.; Wang, B.; Liu, J.; Duan, Y.; Liu, T.; Shan, S.; Yang, K.; et al. Transgenic Overexpression of IL-37 Protects Against Atherosclerosis and Strengthens Plaque Stability. Cell. Physiol. Biochem. 2018, 45, 1034-1050. [CrossRef]

56. Tian, Y.; Chen, T.; Wu, Y.; Yang, L.; Wang, L.; Fan, X.; Zhang, W.; Feng, J.; Yu, H.; Yang, Y.; et al. Pioglitazone stabilizes atherosclerotic plaque by regulating the Th17/Treg balance in AMPK-dependent mechanisms. Cardiovasc. Diabetol. 2017, 16, 140. [CrossRef]

57. Kobiyama, K.; Saigusa, R.; Ley, K. Vaccination against atherosclerosis. Curr. Opin. Immunol. 2019, 59, 15-24. [CrossRef]

58. Lassegue, B.; Griendling, K.K. NADPH oxidases: Functions and pathologies in the vasculature. Arterioscler. Thromb. Vasc. Biol. 2010, 30, 653-661. [CrossRef] [PubMed]

59. Judkins, C.P.; Diep, H.; Broughton, B.R.; Mast, A.E.; Hooker, E.U.; Miller, A.A.; Selemidis, S.; Dusting, G.J.; Sobey, C.G.; Drummond, G.R. Direct evidence of a role for Nox2 in superoxide production, reduced nitric oxide bioavailability, and early atherosclerotic plaque formation in ApoE-/- mice. Am. J. Physiol. Heart Circ. Physiol. 2010, 298, H24-H32. [CrossRef]

60. Gargiulo, S.; Testa, G.; Gamba, P.; Staurenghi, E.; Poli, G.; Leonarduzzi, G. Oxysterols and 4-hydroxy-2-nonenal contribute to atherosclerotic plaque destabilization. Free Radic. Biol. Med. 2017, 111, 140-150. [CrossRef]

61. Martinet, W.; Knaapen, M.W.; De Meyer, G.R.; Herman, A.G.; Kockx, M.M. Elevated levels of oxidative DNA damage and DNA repair enzymes in human atherosclerotic plaques. Circulation 2002, 106, 927-932. [CrossRef]

62. Gargiulo, S.; Rossin, D.; Testa, G.; Gamba, P.; Staurenghi, E.; Biasi, F.; Poli, G.; Leonarduzzi, G. Up-regulation of COX-2 and mPGES-1 by 27-hydroxycholesterol and 4-hydroxynonenal: A crucial role in atherosclerotic plaque instability. Free Radic. Biol. Med. 2018, 129, 354-363. [CrossRef]

63. Prunet, C.; Montange, T.; Vejux, A.; Laubriet, A.; Rohmer, J.F.; Riedinger, J.M.; Athias, A.; Lemaire-Ewing, S.; Neel, D.; Petit, J.M.; et al. Multiplexed flow cytometric analyses of pro- and anti-inflammatory cytokines in the culture media of oxysterol-treated human monocytic cells and in the sera of atherosclerotic patients. Cytometry A 2006, 69, 359-373. [CrossRef] [PubMed]

64. Lamb, F.S.; Choi, H.; Miller, M.R.; Stark, R.J. TNFalpha and Reactive Oxygen Signaling in Vascular Smooth Muscle Cells in Hypertension and Atherosclerosis. Am. J. Hypertens. 2020, 33, 902-913. [PubMed]

65. Kohlgruber, S.; Upadhye, A.; Dyballa-Rukes, N.; McNamara, C.A.; Altschmied, J. Regulation of Transcription Factors by Reactive Oxygen Species and Nitric Oxide in Vascular Physiology and Pathology. Antioxid. Redox Signal. 2017, 26, 679-699. [CrossRef] [PubMed]

66. Yamagata, K. Soy Isoflavones Inhibit Endothelial Cell Dysfunction and Prevent Cardiovascular Disease. J. Cardiovasc. Pharmacol. 2019, 74, 201-209. [CrossRef]

67. Li, W.; Hellsten, A.; Jacobsson, L.S.; Blomqvist, H.M.; Olsson, A.G.; Yuan, X.M. Alpha-tocopherol and astaxanthin decrease macrophage infiltration, apoptosis and vulnerability in atheroma of hyperlipidaemic rabbits. J. Mol. Cell. Cardiol. 2004, 37, 969-978. [CrossRef] [PubMed]

68. Giordano, P.; Scicchitano, P.; Locorotondo, M.; Mandurino, C.; Ricci, G.; Carbonara, S.; Gesualdo, M.; Zito, A.; Dachille, A.; Caputo, P.; et al. Carotenoids and cardiovascular risk. Curr. Pharm. Des. 2012, 18, 5577-5589. [CrossRef]

69. Sozen, E.; Demirel, T.; Ozer, N.K. Vitamin E: Regulatory role in the cardiovascular system. IUBMB Life 2019, 71, 507-515. [CrossRef]

70. Farrell, N.; Norris, G.; Lee, S.G.; Chun, O.K.; Blesso, C.N. Anthocyanin-rich black elderberry extract improves markers of HDL function and reduces aortic cholesterol in hyperlipidemic mice. Food Funct. 2015, 6, 1278-1287. [CrossRef]

71. Quesada, I.M.; Lucero, A.; Amaya, C.; Meijles, D.N.; Cifuentes, M.E.; Pagano, P.J.; Castro, C. Selective inactivation of NADPH oxidase 2 causes regression of vascularization and the size and stability of atherosclerotic plaques. Atherosclerosis 2015, 242, 469-475. [CrossRef]

72. Zhang, H.L.; Jia, K.Y.; Sun, D.; Yang, M. Protective effect of HSP27 in atherosclerosis and coronary heart disease by inhibiting reactive oxygen species. J. Cell. Biochem. 2019, 120, 2859-2868. [CrossRef] [PubMed]

73. Holm Nielsen, S.; Jonasson, L.; Kalogeropoulos, K.; Karsdal, M.A.; Reese-Petersen, A.L.; Auf dem Keller, U.; Genovese, F.; Nilsson, J.; Goncalves, I. Exploring the role of extracellular matrix proteins to develop biomarkers of plaque vulnerability and outcome. $J$. Intern. Med. 2020, 287, 493-513. [CrossRef] [PubMed]

74. Kowara, M.; Cudnoch-Jedrzejewska, A.; Opolski, G.; Wlodarski, P. MicroRNA regulation of extracellular matrix components in the process of atherosclerotic plaque destabilization. Clin. Exp. Pharmacol. Physiol. 2017, 44, 711-718. [CrossRef] [PubMed]

75. Shami, A.; Goncalves, I.; Hultgardh-Nilsson, A. Collagen and related extracellular matrix proteins in atherosclerotic plaque development. Curr. Opin. Lipidol. 2014, 25, 394-399. [CrossRef] [PubMed]

76. Berg, G.; Barchuk, M.; Miksztowicz, V. Behavior of Metalloproteinases in Adipose Tissue, Liver and Arterial Wall: An Update of Extracellular Matrix Remodeling. Cells 2019, 8, 158. [CrossRef] [PubMed]

77. Newby, A.C. Proteinases and plaque rupture: Unblocking the road to translation. Curr. Opin. Lipidol. 2014, 25, 358-366. [CrossRef] [PubMed]

78. Li, T.; Li, X.; Feng, Y.; Dong, G.; Wang, Y.; Yang, J. The Role of Matrix Metalloproteinase-9 in Atherosclerotic Plaque Instability. Mediat. Inflamm. 2020, 2020, 3872367. [CrossRef]

79. Bultmann, A.; Li, Z.; Wagner, S.; Gawaz, M.; Ungerer, M.; Langer, H.; May, A.E.; Munch, G. Loss of protease activity of ADAM15 abolishes protective effects on plaque progression in atherosclerosis. Int. J. Cardiol. 2011, 152, 382-385. [CrossRef] 
80. Johnson, J.L.; Jenkins, N.P.; Huang, W.C.; Di Gregoli, K.; Sala-Newby, G.B.; Scholtes, V.P.; Moll, F.L.; Pasterkamp, G.; Newby, A.C. Relationship of MMP-14 and TIMP-3 expression with macrophage activation and human atherosclerotic plaque vulnerability. Mediat. Inflamm. 2014, 2014, 276457. [CrossRef]

81. Sigala, F.; Savvari, P.; Liontos, M.; Sigalas, P.; Pateras, I.S.; Papalampros, A.; Basdra, E.K.; Kolettas, E.; Papavassiliou, A.G.; Gorgoulis, V.G. Increased expression of bFGF is associated with carotid atherosclerotic plaques instability engaging the NF-kappaB pathway. J. Cell. Mol. Med. 2010, 14, 2273-2280. [CrossRef] [PubMed]

82. Weng, J.; Wang, C.; Zhong, W.; Li, B.; Wang, Z.; Shao, C.; Chen, Y.; Yan, J. Activation of CD137 Signaling Promotes Angiogenesis in Atherosclerosis via Modulating Endothelial Smad1/5-NFATc1 Pathway. J. Am. Heart Assoc. 2017, 6, e004756. [CrossRef]

83. Guo, M.; Cai, Y.; Yao, X.; Li, Z. Mathematical modeling of atherosclerotic plaque destabilization: Role of neovascularization and intraplaque hemorrhage. J. Theor. Biol. 2018, 450, 53-65. [CrossRef]

84. Moreno, P.R.; Purushothaman, K.R.; Fuster, V.; Echeverri, D.; Truszczynska, H.; Sharma, S.K.; Badimon, J.J.; O'Connor, W.N. Plaque neovascularization is increased in ruptured atherosclerotic lesions of human aorta: Implications for plaque vulnerability. Circulation 2004, 110, 2032-2038. [CrossRef] [PubMed]

85. Taruya, A.; Tanaka, A.; Nishiguchi, T.; Matsuo, Y.; Ozaki, Y.; Kashiwagi, M.; Shiono, Y.; Orii, M.; Yamano, T.; Ino, Y.; et al. Vasa Vasorum Restructuring in Human Atherosclerotic Plaque Vulnerability: A Clinical Optical Coherence Tomography Study. J. Am. Coll. Cardiol. 2015, 65, 2469-2477. [CrossRef] [PubMed]

86. Perrotta, P.; Veseli, B.E.; Van der Veken, B.; Roth, L.; Martinet, W.; De Meyer, G.R.Y. Pharmacological strategies to inhibit intra-plaque angiogenesis in atherosclerosis. Vasc. Pharmacol. 2019, 112, 72-78. [CrossRef] [PubMed]

87. Van der Veken, B.; De Meyer, G.R.Y.; Martinet, W. Axitinib attenuates intraplaque angiogenesis, haemorrhages and plaque destabilization in mice. Vasc. Pharmacol. 2018, 100, 34-40. [CrossRef] [PubMed]

88. Sullivan, J.L. Macrophage iron, hepcidin, and atherosclerotic plaque stability. Exp. Biol. Med. 2007, 232, 1014-1020. [CrossRef] [PubMed]

89. Vinchi, F.; Porto, G.; Simmelbauer, A.; Altamura, S.; Passos, S.T.; Garbowski, M.; Silva, A.M.N.; Spaich, S.; Seide, S.E.; Sparla, R.; et al. Atherosclerosis is aggravated by iron overload and ameliorated by dietary and pharmacological iron restriction. Eur. Heart J. 2020, 41, 2681-2695. [CrossRef]

90. Vujic, N.; Schlager, S.; Eichmann, T.O.; Madreiter-Sokolowski, C.T.; Goeritzer, M.; Rainer, S.; Schauer, S.; Rosenberger, A.; Woelfler, A.; Doddapattar, P.; et al. Monoglyceride lipase deficiency modulates endocannabinoid signaling and improves plaque stability in ApoE-knockout mice. Atherosclerosis 2016, 244, 9-21. [CrossRef] [PubMed]

91. Erbay, E.; Babaev, V.R.; Mayers, J.R.; Makowski, L.; Charles, K.N.; Snitow, M.E.; Fazio, S.; Wiest, M.M.; Watkins, S.M.; Linton, M.F.; et al. Reducing endoplasmic reticulum stress through a macrophage lipid chaperone alleviates atherosclerosis. Nat. Med. 2009, 15, 1383-1391. [CrossRef] [PubMed]

92. Gong, M.; Zhuo, X.; Ma, A. STAT6 Upregulation Promotes M2 Macrophage Polarization to Suppress Atherosclerosis. Med. Sci. Monit. Basic Res. 2017, 23, 240-249. [CrossRef] [PubMed]

93. Henning, R.J.; Bourgeois, M.; Harbison, R.D. Poly(ADP-ribose) Polymerase (PARP) and PARP Inhibitors: Mechanisms of Action and Role in Cardiovascular Disorders. Cardiovasc. Toxicol. 2018, 18, 493-506. [CrossRef] [PubMed]

94. Fernandez-Laso, V.; Sastre, C.; Mendez-Barbero, N.; Egido, J.; Martin-Ventura, J.L.; Gomez-Guerrero, C.; Blanco-Colio, L.M. TWEAK blockade decreases atherosclerotic lesion size and progression through suppression of STAT1 signaling in diabetic mice. Sci. Rep. 2017, 7, 46679. [CrossRef] [PubMed]

95. Chen, L.W.; Tsai, M.C.; Chern, C.Y.; Tsao, T.P.; Lin, F.Y.; Chen, S.J.; Tsui, P.F.; Liu, Y.W.; Lu, H.J.; Wu, W.L.; et al. A chalcone derivative, $1 \mathrm{~m}-6$, exhibits atheroprotective effects by increasing cholesterol efflux and reducing inflammation-induced endothelial dysfunction. Br. J. Pharmacol. 2020, 177, 5375-5392. [CrossRef] [PubMed]

96. Cipriani, S.; Francisci, D.; Mencarelli, A.; Renga, B.; Schiaroli, E.; D'Amore, C.; Baldelli, F.; Fiorucci, S. Efficacy of the CCR5 antagonist maraviroc in reducing early, ritonavir-induced atherogenesis and advanced plaque progression in mice. Circulation 2013, 127, 2114-2124. [CrossRef] [PubMed]

97. Tang, X. Analysis of interleukin-17 and interleukin-18 levels in animal models of atherosclerosis. Exp. Ther. Med. 2019, 18, 517-522 [CrossRef]

98. Niessner, A.; Shin, M.S.; Pryshchep, O.; Goronzy, J.J.; Chaikof, E.L.; Weyand, C.M. Synergistic proinflammatory effects of the antiviral cytokine interferon-alpha and Toll-like receptor 4 ligands in the atherosclerotic plaque. Circulation 2007, 116, $2043-2052$. [CrossRef]

99. Khambata, R.S.; Ghosh, S.M.; Rathod, K.S.; Thevathasan, T.; Filomena, F.; Xiao, Q.; Ahluwalia, A. Antiinflammatory actions of inorganic nitrate stabilize the atherosclerotic plaque. Proc. Natl. Acad. Sci. USA 2017, 114, E550-E559. [CrossRef]

100. Kyaw, T.; Winship, A.; Tay, C.; Kanellakis, P.; Hosseini, H.; Cao, A.; Li, P.; Tipping, P.; Bobik, A.; Toh, B.H. Cytotoxic and proinflammatory CD8+ T lymphocytes promote development of vulnerable atherosclerotic plaques in apoE-deficient mice. Circulation 2013, 127, 1028-1039. [CrossRef]

101. Ou, H.X.; Guo, B.B.; Liu, Q.; Li, Y.K.; Yang, Z.; Feng, W.J.; Mo, Z.C. Regulatory T cells as a new therapeutic target for atherosclerosis. Acta Pharmacol. Sin. 2018, 39, 1249-1258. [CrossRef]

102. Fiorelli, S.; Porro, B.; Cosentino, N.; Di Minno, A.; Manega, C.M.; Fabbiocchi, F.; Niccoli, G.; Fracassi, F.; Barbieri, S.; Marenzi, G.; et al. Activation of Nrf2/HO-1 Pathway and Human Atherosclerotic Plaque Vulnerability: An In Vitro and In Vivo Study. Cells 2019, 8, 356. [CrossRef] 
103. Xu, Z.R.; Li, J.Y.; Dong, X.W.; Tan, Z.J.; Wu, W.Z.; Xie, Q.M.; Yang, Y.M. Apple Polyphenols Decrease Atherosclerosis and Hepatic Steatosis in ApoE-/- Mice through the ROS/MAPK/NF-kappaB Pathway. Nutrients 2015, 7, 7085-7105. [CrossRef]

104. Wang, L.; Chen, Q.; Ke, D.; Li, G. Ghrelin inhibits atherosclerotic plaque angiogenesis and promotes plaque stability in a rabbit atherosclerotic model. Peptides 2017, 90, 17-26. [CrossRef]

105. Li, H.; Li, J.; Jiang, X.; Liu, S.; Liu, Y.; Chen, W.; Yang, J.; Zhang, C.; Zhang, W. Melatonin enhances atherosclerotic plaque stability by inducing prolyl-4-hydroxylase alpha1 expression. J. Hypertens. 2019, 37, 964-971. [CrossRef]

106. Budatha, M.; Zhang, J.; Zhuang, Z.W.; Yun, S.; Dahlman, J.E.; Anderson, D.G.; Schwartz, M.A. Inhibiting Integrin alpha5 Cytoplasmic Domain Signaling Reduces Atherosclerosis and Promotes Arteriogenesis. J. Am. Heart Assoc. 2018,7 , e007501. [CrossRef]

107. Parma, L.; Peters, H.A.B.; Sluiter, T.J.; Simons, K.H.; Lazzari, P.; de Vries, M.R.; Quax, P.H.A. bFGF blockade reduces intraplaque angiogenesis and macrophage infiltration in atherosclerotic vein graft lesions in ApoE3*Leiden mice. Sci. Rep. 2020, 10, 15968. [CrossRef] [PubMed]

108. Huang, Z.; Wang, L.; Meng, S.; Wang, Y.; Chen, T.; Wang, C. Berberine reduces both MMP-9 and EMMPRIN expression through prevention of p38 pathway activation in PMA-induced macrophages. Int. J. Cardiol. 2011, 146, 153-158. [CrossRef] [PubMed]

109. Li, H.; He, C.; Wang, J.; Li, X.; Yang, Z.; Sun, X.; Fang, L.; Liu, N. Berberine activates peroxisome proliferator-activated receptor gamma to increase atherosclerotic plaque stability in Apoe(-/-) mice with hyperhomocysteinemia. J. Diabetes Investig. 2016, 7, 824-832. [CrossRef] [PubMed]

110. Yan, H.; Ma, Y.; Li, Y.; Zheng, X.; Lv, P.; Zhang, Y.; Li, J.; Ma, M.; Zhang, L.; Li, C. Insulin inhibits inflammation and promotes atherosclerotic plaque stability via PI3K-Akt pathway activation. Immunol. Lett. 2016, 170, 7-14. [CrossRef]

111. Kagami, S.; Owada, T.; Kanari, H.; Saito, Y.; Suto, A.; Ikeda, K.; Hirose, K.; Watanabe, N.; Iwamoto, I.; Nakajima, H. Protein geranylgeranylation regulates the balance between Th17 cells and Foxp3+ regulatory T cells. Int. Immunol. 2009, 21, 679-689. [CrossRef] [PubMed]

112. Oesterle, A.; Laufs, U.; Liao, J.K. Pleiotropic Effects of Statins on the Cardiovascular System. Circ. Res. 2017, 120, 229-243. [CrossRef] [PubMed]

113. Bot, M.; de Jager, S.C.; MacAleese, L.; Lagraauw, H.M.; van Berkel, T.J.; Quax, P.H.; Kuiper, J.; Heeren, R.M.; Biessen, E.A.; Bot, I. Lysophosphatidic acid triggers mast cell-driven atherosclerotic plaque destabilization by increasing vascular inflammation. $J$. Lipid Res. 2013, 54, 1265-1274. [CrossRef]

114. Gu, C.; Wang, F.; Zhao, Z.; Wang, H.; Cong, X.; Chen, X. Lysophosphatidic Acid Is Associated with Atherosclerotic Plaque Instability by Regulating NF-kappaB Dependent Matrix Metalloproteinase-9 Expression via LPA2 in Macrophages. Front. Physiol. 2017, 8, 266. [CrossRef]

115. Zhang, H.; Zhang, J.Y.; Sun, T.W.; Shen, D.L.; He, F.; Dang, Y.H.; Li, L. Amelioration of atherosclerosis in apolipoprotein E-deficient mice by inhibition of lipoprotein-associated phospholipase A2. Clin. Investig. Med. 2013, 36, E32-E41. [CrossRef]

116. Solly, E.L.; Dimasi, C.G.; Bursill, C.A.; Psaltis, P.J.; Tan, J.T.M. MicroRNAs as Therapeutic Targets and Clinical Biomarkers in Atherosclerosis. J. Clin. Med. 2019, 8, 2199. [CrossRef]

117. Wang, J.; Hu, X.; Hu, X.; Gao, F.; Li, M.; Cui, Y.; Wei, X.; Qin, Y.; Zhang, C.; Zhao, Y.; et al. MicroRNA-520c-3p targeting of RelA/p65 suppresses atherosclerotic plaque formation. Int. J. Biochem. Cell Biol. 2021, 131, 105873. [CrossRef] [PubMed]

118. An, T.H.; He, Q.W.; Xia, Y.P.; Chen, S.C.; Baral, S.; Mao, L.; Jin, H.J.; Li, Y.N.; Wang, M.D.; Chen, J.G.; et al. MiR-181b Antagonizes Atherosclerotic Plaque Vulnerability Through Modulating Macrophage Polarization by Directly Targeting Notch1. Mol. Neurobiol. 2017, 54, 6329-6341. [CrossRef]

119. Chen, W.; Yu, F.; Di, M.; Li, M.; Chen, Y.; Zhang, Y.; Liu, X.; Huang, X.; Zhang, M. MicroRNA-124-3p inhibits collagen synthesis in atherosclerotic plaques by targeting prolyl 4-hydroxylase subunit alpha-1 (P4HA1) in vascular smooth muscle cells. Atherosclerosis 2018, 277, 98-107. [CrossRef]

120. Loyer, X.; Mallat, Z.; Boulanger, C.M.; Tedgui, A. MicroRNAs as therapeutic targets in atherosclerosis. Expert Opin. Ther. Targets 2015, 19, 489-496. [CrossRef]

121. Yiew, K.H.; Chatterjee, T.K.; Hui, D.Y.; Weintraub, N.L. Histone Deacetylases and Cardiometabolic Diseases. Arterioscler Thromb Vasc Biol. 2015, 35, 1914-1919. [CrossRef]

122. Schiano, C.; Benincasa, G.; Franzese, M.; Della Mura, N.; Pane, K.; Salvatore, M.; Napoli, C. Epigenetic-sensitive pathways in personalized therapy of major cardiovascular diseases. Pharmacol. Ther. 2020, 210, 107514. [CrossRef]

123. Zhang, B.; Ma, Y.; Xiang, C. SIRT2 decreases atherosclerotic plaque formation in low-density lipoprotein receptor-deficient mice by modulating macrophage polarization. Biomed. Pharmacother. 2018, 97, 1238-1242. [CrossRef]

124. Pan, Y.; Zhang, H.; Zheng, Y.; Zhou, J.; Yuan, J.; Yu, Y.; Wang, J. Resveratrol Exerts Antioxidant Effects by Activating SIRT2 To Deacetylate Prx1. Biochemistry 2017, 56, 6325-6328. [CrossRef]

125. Pasterkamp, G.; van der Laan, S.W.; Haitjema, S.; Foroughi Asl, H.; Siemelink, M.A.; Bezemer, T.; van Setten, J.; Dichgans, M.; Malik, R.; Worrall, B.B.; et al. Human Validation of Genes Associated With a Murine Atherosclerotic Phenotype. Arterioscler. Thromb. Vasc. Biol. 2016, 36, 1240-1246. [CrossRef]

126. Willemsen, L.; de Winther, M.P. Macrophage subsets in atherosclerosis as defined by single-cell technologies. J. Pathol. 2020, 250, 705-714. [CrossRef] [PubMed]

127. Allahverdian, S.; Pannu, P.S.; Francis, G.A. Contribution of monocyte-derived macrophages and smooth muscle cells to arterial foam cell formation. Cardiovasc. Res. 2012, 95, 165-172. [CrossRef] [PubMed] 
128. Ridker, P.M.; Everett, B.M.; Thuren, T.; MacFadyen, J.G.; Chang, W.H.; Ballantyne, C.; Fonseca, F.; Nicolau, J.; Koenig, W.; Anker, S.D.; et al. Antiinflammatory Therapy with Canakinumab for Atherosclerotic Disease. N. Engl. J. Med. 2017, 377, 1119-1131. [CrossRef] [PubMed]

129. Tardif, J.C.; Kouz, S.; Waters, D.D.; Bertrand, O.F.; Diaz, R.; Maggioni, A.P.; Pinto, F.J.; Ibrahim, R.; Gamra, H.; Kiwan, G.S.; et al. Efficacy and Safety of Low-Dose Colchicine after Myocardial Infarction. N. Engl. J. Med. 2019, 381, 2497-2505. [CrossRef] [PubMed]

130. White, H.D.; Held, C.; Stewart, R.; Tarka, E.; Brown, R.; Davies, R.Y.; Budaj, A.; Harrington, R.A.; Steg, P.G.; The Stability Investigators; et al. Darapladib for preventing ischemic events in stable coronary heart disease. N. Engl. J. Med. 2014, 370, 1702-1711.

131. Bowman, L.; Hopewell, J.C.; Chen, F.; Wallendszus, K.; Stevens, W.; Collins, R.; Wiviott, S.D.; Cannon, C.P.; Braunwald, E. HPS3/TIMI55-REVEAL Collaborative Group; et al. Effects of Anacetrapib in Patients with Atherosclerotic Vascular Disease. N. Engl. J. Med. 2017, 377, 1217-1227. [PubMed]

132. Daida, H.; Dohi, T.; Fukushima, Y.; Ohmura, H.; Miyauchi, K. The Goal of Achieving Atherosclerotic Plaque Regression with Lipid-Lowering Therapy: Insights from IVUS Trials. J. Atheroscler. Thromb. 2019, 26, 592-600. [CrossRef]

133. Schartl, M.; Bocksch, W.; Koschyk, D.H.; Voelker, W.; Karsch, K.R.; Kreuzer, J.; Hausmann, D.; Beckmann, S.; Gross, M. Use of intravascular ultrasound to compare effects of different strategies of lipid-lowering therapy on plaque volume and composition in patients with coronary artery disease. Circulation 2001, 104, 387-392. [CrossRef] [PubMed]

134. Nissen, S.E.; Tuzcu, E.M.; Schoenhagen, P.; Brown, B.G.; Ganz, P.; Vogel, R.A.; Crowe, T.; Howard, G.; Cooper, C.J.; Brodie, B.; et al. Effect of intensive compared with moderate lipid-lowering therapy on progression of coronary atherosclerosis: A randomized controlled trial. JAMA 2004, 291, 1071-1080. [CrossRef] [PubMed]

135. Nicholls, S.J.; Puri, R.; Anderson, T.; Ballantyne, C.M.; Cho, L.; Kastelein, J.J.; Koenig, W.; Somaratne, R.; Kassahun, H.; Yang, J.; et al. Effect of Evolocumab on Progression of Coronary Disease in Statin-Treated Patients: The GLAGOV Randomized Clinical Trial. JAMA 2016, 316, 2373-2384. [CrossRef]

136. Christoph, M.; Herold, J.; Berg-Holldack, A.; Rauwolf, T.; Ziemssen, T.; Schmeisser, A.; Weinert, S.; Ebner, B.; Said, S.; Strasser, R.H.; et al. Effects of the PPARgamma agonist pioglitazone on coronary atherosclerotic plaque composition and plaque progression in non-diabetic patients: A double-center, randomized controlled VH-IVUS pilot-trial. Heart Vessel. 2015, 30, 286-295. [CrossRef]

137. Thondapu, V.; Kurihara, O.; Yonetsu, T.; Russo, M.; Kim, H.O.; Lee, H.; Soeda, T.; Minami, Y.; Jang, I.K. Comparison of Rosuvastatin Versus Atorvastatin for Coronary Plaque Stabilization. Am. J. Cardiol. 2019, 123, 1565-1571. [CrossRef]

138. Geng, C.; Zhang, Y.; Hidru, T.H.; Zhi, L.; Tao, M.; Zou, L.; Chen, C.; Li, H.; Liu, Y. Sonodynamic therapy: A potential treatment for atherosclerosis. Life Sci. 2018, 207, 304-313. [CrossRef]

139. Yoo, S.W.; Oh, G.; Ahn, J.C.; Chung, E. Non-Oncologic Applications of Nanomedicine-Based Phototherapy. Biomedicines 2021, 9 , 113. [CrossRef]

140. Kharlamov, A.N.; Tyurnina, A.E.; Veselova, V.S.; Kovtun, O.P.; Shur, V.Y.; Gabinsky, J.L. Silica-gold nanoparticles for atheroprotective management of plaques: Results of the NANOM-FIM trial. Nanoscale 2015, 7, 8003-8015. [CrossRef] [PubMed]

141. Scoville, D.K.; Nolin, J.D.; Ogden, H.L.; An, D.; Afsharinejad, Z.; Johnson, B.W.; Bammler, T.K.; Gao, X.; Frevert, C.W.; Altemeier, W.A.; et al. Quantum dots and mouse strain influence house dust mite-induced allergic airway disease. Toxicol. Appl. Pharmacol. 2019, 368, 55-62. [CrossRef] [PubMed]

142. Jia, H.; Dai, J.; Hou, J.; Xing, L.; Ma, L.; Liu, H.; Xu, M.; Yao, Y.; Hu, S.; Yamamoto, E.; et al. Effective anti-thrombotic therapy without stenting: Intravascular optical coherence tomography-based management in plaque erosion (the EROSION study). Eur. Heart J. 2017, 38, 792-800. [CrossRef] [PubMed]

143. Baigent, C.; Blackwell, L.; Collins, R.; Emberson, J.; Godwin, J.; Peto, R.; Buring, J.; Hennekens, C.; Kearney, P.; Antithrombotic Trialists' Collaboration; et al. Aspirin in the primary and secondary prevention of vascular disease: Collaborative meta-analysis of individual participant data from randomised trials. Lancet 2009, 373, 1849-1860. [PubMed]

144. Shioi, A.; Ikari, Y. Plaque Calcification During Atherosclerosis Progression and Regression. J. Atheroscler. Thromb. 2018, 25, 294-303. [CrossRef] 